\title{
A review of the genus Bulbothrix Hale: the isidiate, sorediate, and pustulate species with medullary salazinic acid
}

\section{Benatti $\mathrm{MN}^{1}$}

\author{
${ }^{1}$ Instituto de Botânica, Núcleo de Pesquisa em Micologia, Caixa Postal 68041, São Paulo / SP, CEP 04045-972, Brazil \\ e-mail: michel_benatti@yahoo.com.br
}

Benatti MN 2013 - A review of the genus Bulbothrix Hale: the isidiate, sorediate, and pustulate species with medullary salazinic acid. Mycosphere 4(1), 1-30, Doi 10.5943 /mycosphere/4/1/1

This study is a taxonomic review of ten Bulbothrix (Parmeliaceae, Lichenized Fungi) species containing salazinic acid in the medulla that reproduce by vegetative propagation or form pustules that erode into coarse granules. The current species delimitations are confirmed. New characteristics are detailed, some synonyms are rejected, others confirmed, and range extensions are added.

Key words - bulbate cilia - norstictic acid - Parmeliaceae - Parmelinella

Article Information

Received 27 November 2012

Accepted 10 December 2012

Published 23 January 2013

*Coresponding Author: Michel N. Benatti-e-mail - michel_benatti@yahoo.com.br

\section{Introduction}

Bulbothrix Hale was proposed for a group of species previously called Parmelia Series Bicornutae (Lynge) Hale \& Kurokawa (Hale 1974), characterized by small, laciniate and usually adnate thalli, simple to branched bulbate marginal cilia, cortical atranorin, simple to branched rhizinae, smooth to coronate apothecia, hyaline unicellular ellipsoid to bicornute ascospores 5.0-21.0 $\times$ 4.0-12.0 $\mu \mathrm{m}$, and bacilliform to bifusiform conidia 5.0-10.0 × 0.5-1.0 $\mu \mathrm{m}$ (Hale 1976, Elix 1993a). Crespo et al. (2010) presented a revised generic concept of Parmelioid lichens based on molecular, morphological and chemical evidence and included other diagnostic features such as a pored epicortex, lack of cortical pseudocyphellae, and presence of isolichenan in the cell walls. Bulbothrix is currently nested in the Parmelina clade and some species are grouped with Parmelinella, making the genus paraphyletic (Crespo et al.
2010).

This paper deals with several of the species related to Parmelinella, as did a previous one (Benatti 2012c). Recent molecular research (Divakar et al. 2006, Crespo et al. 2010) points out that Bulbothrix species containing medullar salazinic acid may actually belong to Parmelinella, or even be another small genus closely related to it. Eventually, with the advancement of research to resolve open questions about the phylogeny of many species that constitute Bulbothrix, including the type, species with bicornute ascospores containing salazinic acid might eventually turn out to still be included in the genus or perhaps form a new one.

During a revision of the genus Bulbothrix (Benatti 2010) the type specimen and additional material of Bulbothrix was studied. These species have cilia with hollow basal bulbs, which contain differentiated (round) cells and a characteristic oily substance 
(Hale 1975, Feuerer \& Marth 1997, Benatti 2011). The first published part of Benatti's (2010) thesis concerns new combinations of four species, Hypotrachyna tuskiformis (Elix) Benatti \& Marcelli, Parmelinopsis pinguiacida (Louwhoff \& Elix) Marcelli \& Benatti, $P$. subinflata (Hale) Benatti \& Marcelli and Parmotrema yunnanum (Sheng L. Wang, J.B. Chen \& Elix) Marcelli \& Benatti, previously placed in Bulbothrix (Benatti \& Marcelli 2010) and excluded due to the lack of true bulbate cilia. The second part treats the species containg medullary norstictic and protocetraric acids (Benatti 2012a). The third part treats the species with medullary salazinic acid that do not form isidia, soredia, lacinulae or pustules (Benatti 2012c).

It is planned to publish six papers to provide a comprehensive understanding and easy assessment of all the data on this genus (comprising ca. 60 species) gathered in an unpublished study by Benatti (2010). The six parts are: (I) species containing medullary norstictic and protocetraric acid; (II) species containing salazinic acid lacking vegetative propagules (both already published, see Benatti 2012a, 2012c); (III) species containing salazinic acid with vegetative propagules (this paper); (IV) species containing fatty acids or no medullary substances; (V) species containing the gyrophoric/lobaric/lecanoric acids lacking vegetative propagules; and (VI) species containing the gyrophoric/lobaric/lecanoric with vegetative propagules. This will ultimately result in a synthesis of the whole genus followed by a worldwide key. A discussion about all the motives for such an extensive and detailed treatment and the problems faced while working the review is explained in Benatti (2012c).

This paper discusses the ten species with medullary salazinic acid [Bulbothrix australiensis Hale, B. decurtata (Kurok.) Hale, B. imshaugii (Hale) Hale, B. isidiza (Nyl.) Hale, B. microscopica Elix, B. pustulata (Hale) Hale, $B$. subglandulifera (Hue) Hale, $B$. subscortea (Asahina) Marcelli \& Benatti, $B$. subtabacina (Elix) Elix and B. tabacina (Mont. $\&$ Bosch) Hale], that do form isidia, soredia, or pustules.

\section{Material and methods}

Type material and additional species were studied from BM, CANB, DUKE, $\mathrm{H}$, HUFSCAr, L, LD, MEL, MSC, NY, PC, SP, TNS, and US, originating from Oceania, Asia, North Pacific Ocean islands, Africa, North America, Central America, Caribbean, and South America, as well as material collected in Brazil during the last 30 years, mainly by the author and members of the Lichenological Study Group of the Instituto de Botânica (GEL) in Brazil.

The methodology and conventions are detailed in Benatti (2012a). Bulbs on cilia, rhizines, apothecia and other thallus parts were checked using the clarification method (Benatti 2011). Chemical constituents of the additional specimens examined were identified by thinlayer chromatography (TLC) using solvent $\mathrm{C}$ (Bungartz 2001), and compared with the data on labels left with the specimens. The types had their chemical constituents examined by high performance liquid chromatography (HPLC), following the methods described in Elix et al. (2003).

The presence of salazinic acid is evidenced by a $\mathrm{K}+$ yellow $\rightarrow$ dark red spot test reaction. Its presence is also sometimes perceived by the formation of bundles of thin elongated shaped crystals of a deep reddish colour, observed under a light microscope after the transfer of hyphae onto a microscope slide and dropping the reagent on the fungal material, such as cutting a small piece of the thallus or of the apothecia. However, unlike the crystals of norstictic acid (Benatti 2012a), the crystals of salazinic acid depends on a higher concentration of the substance and take longer to crystallize.

The species selected for comparisons are those that show close morphological or chemical similarities, and those most often compared by other authors due to peculiar characteristics.

\section{Results and discussion}

The study confirmed ten species containing medullar salazinic acid that do form vegetative propagules (mainly isidia, but also soredia), or pustules. All species are described 
in detail and their diagnostic characters are discussed, with many unknown details about the morphology and secondary metabolites of each taxa being clarified.

With the exception of Bulbothrix pustulata that is pustulate and B. imshaugii that is sorediate, all other species are isidiate. Bulbothrix australiensis, B. microscopic, B. pustulata, $B$. subglandulifera and $B$. subtabacina are corticolous, while $B$. decurtata and $B$. subscortea are saxicolous. Bulbothrix imshaugii and $B$. isidiza are predominatly corticolous, rarely saxicolous.

\section{The species}

Bulbothrix australiensis Hale. Mycotaxon 25: 85. 1986.

Mycobank MB 104075

Fig.1

Holotype - Australia, New South Wales, Ku-rin-gai National Park, observation point, on tree in park area, leg. M.E. Hale 59360, 20-I-1982 (US!, MEL isotype n.v.).

Thallus sublinear laciniate, pale dusky grey in herbarium, up to $3.2 \mathrm{~cm}$ in diam., subcoriaceous, corticicolous, upper cortex 12.5-17.5 $\mu \mathrm{m}$ thick, algal layer $15.0-27.5 \mu \mathrm{m}$ thick, medulla 75.5-90.0 $\mu \mathrm{m}$ thick, lower cortex 15.0-17.5 $\mu \mathrm{m}$ thick. Laciniae anisotomic to irregularly dichotomously branched, $0.6-2.0 \mathrm{~mm}$ wide, contiguous to slightly imbricate, strongly adnate and adpressed, with flat, subtruncate to truncate apices, margins plane, smooth and sinuous to crenate or subirregular, entire, scarcely sublacinulate, axils oval. Upper surface smooth and continuous, becoming slightly rugose and irregularly cracked in some parts, laminal ciliar bulbs absent. Adventitious marginal lacinulae scarce and restricted to older parts, short, $0.2-0.6 \times 0.1-0.2 \mathrm{~mm}$, plane, simple, apices truncate, lower side concolorous to the lower marginal zone. Maculae absent. Cilia black to partially brown, apices simple or sometimes not distinct, $0.05-0.35 \times$ ca. $0.03 \mathrm{~mm}$, with sessile to emergent bulbate bases $0.05-0.30$ $\mathrm{mm}$ wide, the bases eventually enlarged and reniform, abundant along the margin, spaced ca. $0.05 \mathrm{~mm}$ from each other, or contiguous, solitary or in small groups at the crenae and axils, scarce to absent at the apices of the laciniae. Soredia and pustules absent. Isidia frequent, laminal to occasionally marginal, granular to smooth cylindrical, straight to slightly tortuous, $0.05-1.10 \times(0.05-) 0.10 \mathrm{~mm}$, simple but occasionally slightly branched, erect, firm to \pm caducous, usually with brown apices, eciliate. Medulla white. Lower surface brown to pale brown, shiny, smooth, weakly papillate, moderately rhizinate. Marginal zone brown to pale brown, indistinct from the center to occasionally somewhat darker, shiny, smooth, weakly papillate, weakly rhizinate. Rhizinae brown to black, commonly with whitish apices, simple, commonly with blackish bulbate bases, $0.05-0.45 \times 0.03-0.05$ $\mathrm{mm}$, frequent but becoming scarcer close to the margins, evenly distributed. Apothecia not found (accordingly to Hale 1986 and Elix 1994, they are sessile to adnate, $0.8-1.0 \mathrm{~mm}$ in diam., ecoronate, only immature ascospores were found). Pycnidia common, laminal to submarginal, immerse, with black ostioles. Conidia bacilliform to weakly bifusiform, $5.0-6.0 \times$ ca. $1.0 \mu \mathrm{m}$.

TLC/HPLC: cortical atranorin and chloroatranorin, medullary salazinic acid (see also Hale 1976, Elix 1994).

Distribution - Oceania: Australia (Hale 1986, Elix 1994).

Additional specimens examined Australia, New South Wales, South Coast District, Honeysuckle Bay, Murramarong National Park, $10 \mathrm{~km} \mathrm{~N}$ of Batemans Bay, on bark, $35^{\circ} 38^{\prime} \mathrm{S}, 150^{\circ} 15^{\prime} \mathrm{E}$, leg. K. Ralston 2628 , 2-VII-2002 (MEL). Idem, Queensland, Keperra, near corner Glengarry Road and Uper Kedron Road, on Acacia sp., leg. R. Rogers \& C. Beasley 3408, 12-V-1975 (MEL).

Comments - The holotype (Fig. 1) consists of several small fragments in good condition, on bark, not being glued on cardboard. There are several isidia at different stages of maturation, but no apothecia were found in the material, although pycnidia are common. The isotype mentioned by Hale (1986) was not located. Only immature ecoronate apothecia are known for Bulbothrix australiensis, without a description of ascospores.

There is no sign of maculae in the upper cortex of any of the specimens studied. The 
isidia are thick and robust, often above $0.5 \mathrm{~mm}$ high, and in some parts they can become densely branched, reaching more than $1 \mathrm{~mm}$ in height. The rhizines have conspicuous and dark bulbate bases, similar to those of the cilia.

This species was compared by Hale (1986) to B. subtabacina and B. isidiza. The first differs by the strongly maculate and strongly cracked upper cortex, narrower laciniae (ca. 0.5-1.0 mm wide), cilia with more subtle bulbs and branched apices, by the smaller, often simple and ciliate isidia, a black lower cortex, and by the the dichotomously branched rhizines without basal bulbs. The second differs by its maculate upper cortex, and smaller, mostly simple isidia, and its wider, more irregularly branched laciniae ca. 1.5-5.0 mm with rounded apices, and paler rhizines that lack bulbate bases.

Some small specimens of $B$. isidiza collected on substrates in which they had little room to develop have laciniae with minimum widths for the species, and can resemble those of B. australiensis, but these are always maculate. Even in well developed specimens of $B$. australiensis the laciniae are always emaculate, more sublinear, with truncate apices, not exceeding $2 \mathrm{~mm}$ in width.

Among other relatively similar species, B. tabacina (L! lectotype, PC! duplicate) differs from $B$. australiensis by nearly identical characters as $B$. isidiza, except this species has a black lower cortex. Bulbothrix cinerea Marcelli \& Kalb differs by its saxicolous growth habit, the usually brown or blackish, simple and smaller isidia, and by the presence of medullary norstictic acid.

Bulbothrix decurtata (Kurok.) Hale. Phytologia 28: 480. $1974 . \quad$ Figs 2-3 Mycobank MB 341597

Basyonym - Parmelia decurtata Kurok. Contributions from the United States National Herbarium 36: 139. 1964.

Holotype - Union of South Africa, Transvaal, District Lydenburg, 10 miles SE of Lydenburg on sandstone rocks near road, leg. O. Almborn 7388, 20-X-1953 (LD!, isotype at US!).

Thallus subirregular to sublinear laciniate or sublaciniate, greyish olivaceous green in herbarium, fragments up to $8.5 \mathrm{~cm}$ in diam., coriaceous, saxicolous, upper cortex 22.5-40.0 $\mu \mathrm{m}$ thick, algal layer $42.5-65.0 \mu \mathrm{m}$ thick, medulla 100.0-130.0 $\mu \mathrm{m}$ thick, lower cortex 27.5-50.0 $\mu \mathrm{m}$ thick. Laciniae anisotomic to irregularly dichotomously branched, 0.6-2.8 (-3.5) mm wide, contiguous to imbricate becoming partially crowded at the center, strongly adnate and adpressed, with plane to slightly involute, subtruncate apices, the margins plane, sinuous to subcrenate or irregular, entire, scarcely sublacinulate, the axils oval. Upper surface smooth, irregularly cracked except by the younger distal parts, laminal ciliar bulbs absent. Adventitious marginal lacinulae scarce on random parts, short, $0.5-0.6 \times 0.2-0.4 \mathrm{~mm}$, plane, simple or irregularly branched, apices truncate, lower side concolorous with the lower marginal zone. Maculae absent. Cilia black, apices simple or absent, frequently bent downwards, 0.05-0.40 $\times$ ca. $0.03 \mathrm{~mm}$, with semi-immerse to sessile bulbate bases (0.05-) $0.10-0.15(-0.25) \mathrm{mm}$ wide, these sometimes stretched and wilted, frequent throughout the margins, spaced 0.05-0.10 $\mathrm{mm}$ from each other becoming contiguous at the axils, to scarce at the apices of the laciniae. Soredia, and pustules absent. Isidia frequent, laminal, granular to short smooth cylindrical with a papillar aspect, straight, $0.05-0.10(-0.15) \times$ ca. $0.05 \mathrm{~mm}$, simple, erect, firm to \pm caducous, usually blackened and shiny already as soon as the isidia are being formed (sometimes the blackening is restricted to their apices), eciliate. Medulla white. Lower surface black to occasionally dark brown, shiny to opaque, smooth to subrugose, moderately rhizinate. Marginal zone brown to dark brown, black or variegated, attenuated to indistinct from the center, ca. $0.5-1.5 \mathrm{~mm}$ wide, shiny to opaque, smooth, moderately rhizinate. Rhizinae black to brown, occasionally with whitish apices when close to the margins, simple to occasionally irregularly branched, often with bulbate bases, $0.10-0.60(-0.90) \times$ ca. 0.05 $(-0.10) \mathrm{mm}$, frequent but becoming scarcer at the margins, occasionally adglutinated, evenly 

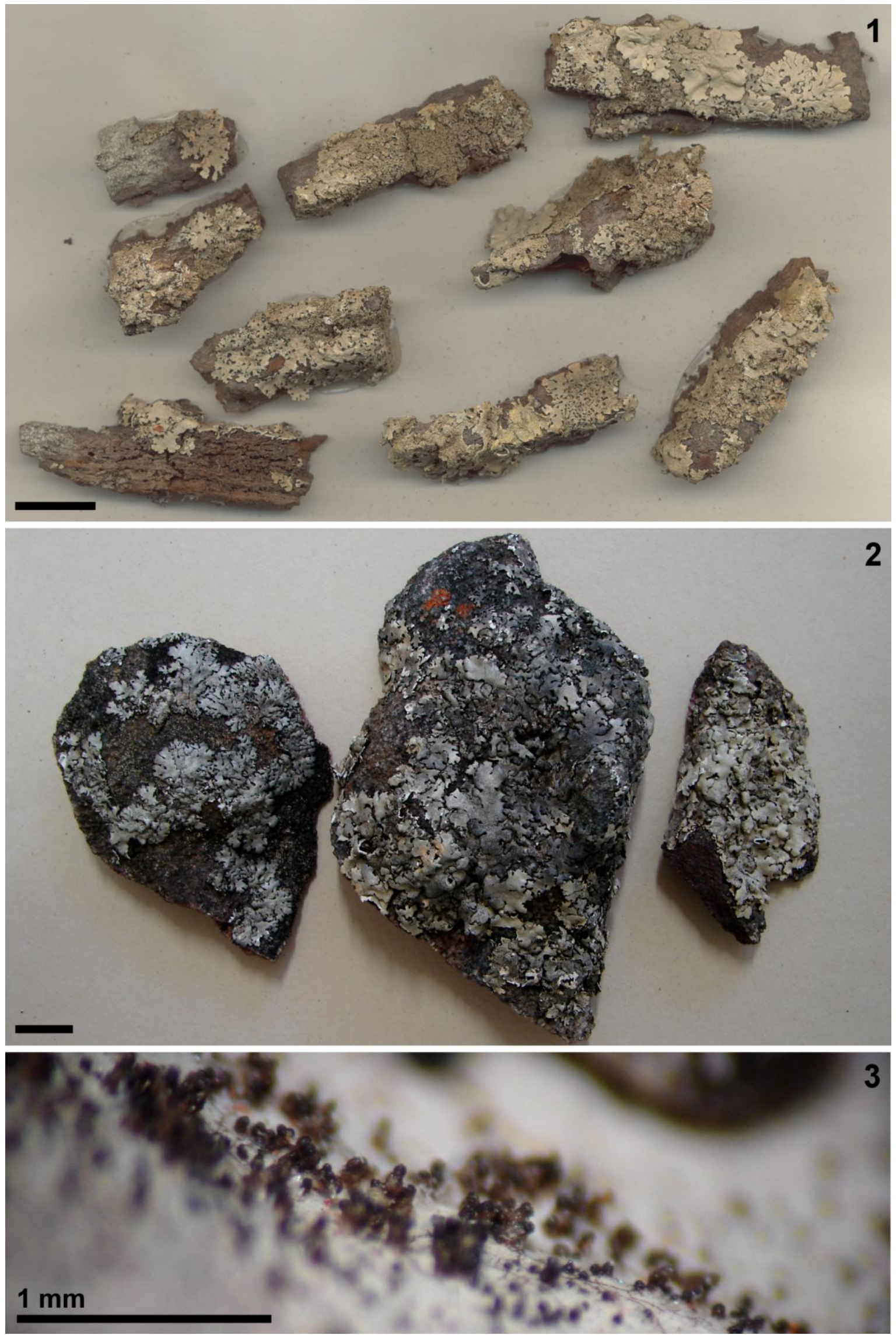

Figs 1-3 - 1 Holotype of Bulbothrix australiensis (US). 2 Holotype of Bulbothrix decurtata (LD). 3 Detail of the small blackish isidia of the holotype. Scale bars $=1 \mathrm{~cm}(1,2), 1 \mathrm{~mm}(3)$. 
distributed. Apothecia not found. Pycnidia submarginal, scarce, immerse, with black ostioles. Conidia weakly to distinct bifusiform, occasionally their cell lumina of unequal size, $5.0-9.0 \times$ ca. $1.0 \mu \mathrm{m}$.

TLC/HPLC - cortical atranorin, medullary salazinic acid (see also Hale \& Kurokawa 1964, Hale 1976).

Distribution - Africa: South Africa (Hale \& Kurokawa 1964), Ivory Coast, and Uganda (Hale 1976).

Additional specimens examined South Africa, Natal, District Bergville, Cathedral Peak Area, alt. 6000 ft. Indument Forest, on sandstone rocks, leg. O. Almborn 9328, 6-XI-1953 (LD, NY); idem, O. Almborn 9329, 6-XI-1953 (MSC); idem, Cape Province, Simonstown District, Cape of Good Hope Nature Reserve, S.H. Skaife Field Station at Olofantsbosbaai, 3418 AD, seaside cliffs with scattered trees, leg. W.R. Buck 13866, 21-I1986 (NY); idem, Transvaal, Tzaneen District, Woodbush Forest Reserve, around radio masts near Houbosdorp at Schnellskop, $2330 \mathrm{CC}$, 2050 m, dwarf Forest with rock flats, leg. R.C. Harris 18609, 12-I-1986 (NY).

Comments - The holotype (Fig. 2) consists of three fragments in good condition, growing on rock glued to cardboard. The isotype consists of a single fragment in the same conditions as the holotype. None of the type materials displays apothecia, even rudimentary ones, and few pycnidia were found, some with conidia. Apothecial characteristics are unknown.

Swinscow \& Krog (1988) considered $B$. decurtata a synonym of $B$. tabacina (L! lectotype, duplicate at PC!), claiming that it was only a saxicolous form and that it did not differ significantly. Due comparisons between the specimens studied, and the consistent differences found between the specimens, $B$. decurtata is accepted here as a distinct species. It is possible that part of the material examined by Swinscow \& Krog (1988) are saxicolous specimens of $B$. tabacina intermixed with true $B$. decurtata. A loan of the material was requested several times from herbarium $\mathrm{O}$, but all requests were unanswered.

The thallus surface of $B$. decurtata is very cracked, except for the young parts, somewhat similar to what occurs in the rimose thalli of Parmotrema species with reticulate maculae (ex Rimelia), even though this species has none. The isidia are unique and easy to distinguish from specimens of $B$. tabacina, since early in its formation they are blackened and bright, with a papillate aspect. In the light microscope they show the typical anatomical structure, covered by a thin, dark "skin", of uncertain origin. Most isidia are entirely darkened, while some, usually the taller ones, have the darkening restricted to their apices. Both cilia or pycnidia are often formed from the isidia.

Hale (1976) mentioned that $B$. decurtata appeared to be the only obligatory saxicolous species of the genus, but a few others have been discovered since. The author also commented on a single anomalous specimen due to the additional presence of the substance norlobaridone found together with salazinic acid, but noting that the specimen was indistinguishable from the normal population of the species.

Bulbothrix tabacina (L! lectotype, PC! duplicate) was the only species compared to $B$. decurtata in literature (Hale \& Kurokawa 1964). Despite the similarities (presence of isidia, bulbate cilia with simple apices, medullary salazinic acid spinal cord), they can be differentiated by the fact that $B$. decurtata has an emaculate, very cracked upper cortex, narrower subtruncate laciniae, cilia often without apices, and by the smaller, blackened and bright isidia, a somewhat variable lower cortex colour, besides also being strictly saxicolous.

Bulbothrix isidiza (H-Nyl!, holotype), is also isidiate and presents medullary salazinic acid, but differs by the presence of upper cortex maculae, the pale brown lower cortex, and the larger, concolorous isidia often with darkened apices. As with B. tabacina, it is also primarily found corticolous.

Bulbothrix cinerea (Kalb pers. herb!, holotype), which also appears to be a strictly saxicolous species, differs by the somewhat relatively narrower laciniae, generally $0.5-1.5$ $(-2.5) \mathrm{mm}$ wide, a pale brown lower cortex and of rhizines, and by the presence of acid medullary norstictic acid. 
Interestingly, thalli of $B$. cinerea also tend to have blackened isidia much like those found on B. decurtata (Fig. 3). However, the isidia blackening of $B$. cinerea more often become eventually restricted only to the apices, not enveloping the isidia as much as in $B$. decurtata. Developed isidia of $B$. cinerea are partly dilated (due a common presence of a parasitic fungi as found on specimens studied) or sometimes flatten acquiring lobule aspect, being also larger and thicker than those found on B. decurtata (Benatti 2012a).

Bulbothrix ventricosa (Hale \& Kurok.) Hale (TUR-V! lectotype) is only found corticolous, and also differs by the constant development of laminal ciliar bulbs, larger concolorous isidia partially with brownish apices, a variable, often mixed coloration of the lower cortex, and by the presence of medullary norstictic (Benatti 2012a).

Bulbothrix imshaugii (Hale) Hale. Phytologia 28: 480. 1974.

Mycobank MB 341601

Fig.4

Basyonym - Parmelia imshaugii Hale. Phytologia 22: 31. 1971.

Holotype - Chile, Prov. Valparaiso, Montana Campana, coastal range, near Granizo, root of Notofagus, elevation $4000 \mathrm{ft}$., leg. H. A. Imshaug 36670, 21-XI-1965 (MSC!, isotype at US!).

Thallus subirregular to partially sublinear laciniate, whitish dusky grey in herbarium, fragments up to $4.7 \mathrm{~cm}$ in diam., subcoriaceous, corticolous or rarely saxicolous, upper cortex $17.5-22.5 \mu \mathrm{m}$ thick, algal layer 25.0-37.5 $\mu \mathrm{m}$ thick, medulla 85.0-110.0 $\mu \mathrm{m}$ thick, lower cortex 17.5-27.5 $\mu \mathrm{m}$ thick. Laciniae irregularly to partially anisotomic dichotomously branched, (1.4-) 2.1-4.6 mm wide, contiguous, slightly adnate and adpressed, with subplane, subtruncate to irregular apices, the margins subplane, smooth to crenate or irregular, incised, occasionally sublacinulate, the axils oval to irregular. Upper cortex smooth and continuous, becoming subrugose with occasional irregular cracks on older or densely sorediate parts, laminal ciliar bulbs absent. Adventitious marginal lacinulae scarce, randomly scattered, short (although sometimes wide), $0.2-0.5 \times 0.2-2.0 \mathrm{~mm}$, plane, simple or irregularly branched, apices truncate, lower side concolorous to the lower marginal zone. Maculae distinct, punctiform to effigurate, laminal. Cilia black, apices simple, rarely furcate or irregularly branched, 0.05$0.35 \times$ ca. $0.03 \mathrm{~mm}$, with semi-immerse to sessile bulbate bases $0.05-0.10(-0.20) \mathrm{mm}$ wide, frequent throughout the margins, in small groups at the crenae, spaced $0.05-0.15 \mathrm{~mm}$ from each other, becoming contiguous at the axils, occasionally juxtaposed as if they were fused, usually scarce at the apices of the laciniae. Soralia subcapitate or irregular, laminal to occasionally subapical, initially hemispheric becoming flattened and extensive, apparently arising by gradual disintegration of the upper cortex, soredia farinose to \pm subgranular, 20.0-55.0 (-90.0) $\mu \mathrm{m}$ in diam. Pustules and isidia absent (although some small soralia have a pustular aspect). Medulla white. Lower surface black, shiny, smooth, to subrugose, moderate to densely rhizinate in the center, occasionally less densely rhizinate along the margins. Marginal attenuated, 0.5$2.5 \mathrm{~mm}$ wide, brown to occasionally black, opaque to shiny, smooth to subrugose, weakly papillate, becoming rhizinate towards the center. Rhizinae black, occasionally dark brown at the margins, simple to rarely furcate, without bulbate bases or displaced bulbs, 0.10$0.60(-0.80) \times$ ca. $0.03 \mathrm{~mm}$, frequent at the margins becoming abundant at the center, evenly distributed. Apothecia not found (accordingly to Hale 1976, they are substipiate, 2.0-4.0 $\mathrm{mm}$ in diam., ecoronate, with 8 ascospores per ascus, measuring $8.0 \times 4.0 \mu \mathrm{m}$ ). Pycnidia not found.

TLC/HPLC - cortical atranorin, medullary salazinic acid (see also Hale 1971, 1976).

Distribution - South America: Argentina (Calvelo \& Adler 1999), Chile (Hale 1971, 1976, Galloway \& Quilhot 1998) and Venezuela (López-Figueiras 1986, Marcano et al. 1996).

Additional specimens examined: Chile, National Park La Campana, $33^{\circ} \mathrm{S}$, over Nothofagus obliqua, leg. G. Guzmán 3368, 26II-1985 (US); idem, over rock, 1000 m, G. Guzmán 3357, 26-II-1985 (US); idem, Prov. Santiago, $8 \mathrm{~km} \mathrm{~W}$ of Tiltil, shrub chaparral 
(IBP Primary Site), on east slope of Cuesta de la Dormida, 1000-1300 m, on shaded boulder in ravine, leg. W.A. Weber \& B. Johnston s.n., 9-XI-1976 (US); idem, Cuesta de la Dormida, east slope, on trunk of Nothofagus obliqua (Mirb.) Oerst., 950 m, leg. P.W. Rundel 7316, 29-VII-1972 (US).

Comments - This was the first sorediate Bulbothrix species described (Hale 1971). Besides B. imshaugii, this kind of propagule is known for only one other species in the genus, B. leprieurii Aubel (Sipman \& Aubel 1992). Both species are only known from South America.

The holotype (Fig. 4) consists of six fragments in good condition on soft bark of roots from Notofagus obliqua (Mirb.) Oerst., with soralia on all of them. Although the fragments are not glued to cardboard, most of them are still attached to their substrate. The material is very brittle. The isotype is a large fragment, larger than those of the holotype, and under the same conditions, but partially glued to cardboard. Part of the isotype soralia were damaged (compressed) or with few soredia. There are no apothecia or pycnidia in any of the type specimens fragments.

At early stages, the soralia in $B$. imshaugii are somewhat similar to the pustular soralia found on specimens of B. leprieurii (U!, holotype), but they soon become flattened and spread over the upper cortex. Unlike those on $B$. leprieurii, the soralia of $B$. imshaugii do not erode until exposed, the medulla and the upper portion of the lower cortex being more similar to those on Canoparmelia texana (Tuck.) Hale $\&$ Elix, for example. The soredia of $B$. imshaugii are somewhat finer compared to those of $B$. leprieurii. The upper cortex of $B$. imshaugii is strongly maculate, causing a whitish appearance to the herbarium specimens. There are many transverse cracks on the specimens, specially at older parts or on the more sorediate laciniae.

Besides the more granular soredia formed at capitate or pustular soralia, that usually originate at the apical portions of the laciniae, Bulbothrix leprieurii also differs from $B$. imshaugii by the narrower emaculate laciniae (0.3-0.7 $\mathrm{mm}$ wide), and by the presence of medullary gyrophoric acid (main substance) with variable amounts of lecanoric and orsellinic acids, instead of the salazinic acid.

Calvelo \& Adler (1999) mentioned a single specimen as $B$. imshaugii with much longer cilia than those seen in the material examined here $(0.1-1.5 \mathrm{~mm}$ long). The authors also noticed a pustular origin of some soralia, and while they did mention the occasional presence of basal bulbs in the rhizines, these were not observed here.

None of the morphologically close species containing medullary salazinic acid develop soredia. Bulbothrix pustulata (US!, holotype, $\mathrm{LG}$ and $\mathrm{O}$ isotypes n.v.) differs by the formation of pustules, which tend to remain intact, that occasionally could form rough granules by disintegration of the cortex, instead of forming soralia with typical soredia grains. Bulbothrix pustulata is an emaculate species with larger ascospores, 9.0-14.0 $\times 6.0-8.0 \mu \mathrm{m}$.

Bulbothrix tabacina (L! lectotype, PC! duplicate) and B. isidiza (H-Nyl! holotype) both differ by forming isidia instead of soredia, the weaker maculae, a more continuous upper cortex, and larger ascospores ca. 12.0-16.0 $\times$ 6.0-9.0 $\mu \mathrm{m}$. Bulbothrix isidiza also differs by the pale brown colour of the lower cortex.

Bulbothrix meizospora (Nyl.) Hale (HNyl!, holotype) and B. hypocraea (TUR-V!, lectotype, BM!, duplicate) both differ by forming only apothecia, a continuous upper cortex, and by their larger ascospores, respectively $12.0-22.0 \times 8.0-14.0 \mu \mathrm{m}$ and $8.0-14.0 \times 6.0-8.0 \mu \mathrm{m}$. Thalli of $B$. hypocraea also differ by a pale brown lower cortex.

Bulbothrix setschwanensis (Zahlbr.) Hale (WU!, lectotype) and B. sensibilis (J. Steiner \& Zahlbr.) Hale (W!, holotype) also differ by having a continuous upper cortex and by forming only apothecia, the first with ascospores ca. $5.0 \times 4.0 \mu \mathrm{m}$ while the second has ascospores $8.0-12.0 \times 6.0-8.0 \mu \mathrm{m}$. Thalli of $B$. setschwanensis are also emaculate and have a pale brown lower cortex.

Hale (1971) compared B. imshaugii only to Parmelia brevirhiza Kurok. [= Hypotrachyna brevirhiza (Kurok.) Hale], due the overall aspect and by the fact that both have the same medullary substance salazinic acid. As cited by Hale, the species are 
distinguishable by the absence of marginal cilia and by the formation of dichotomously branched rhizines in Hypotrachyna brevirhiza.

Bulbothrix isidiza (Nyl.) Hale. Phytologia 28(5): 480. 1974.

Figs 5-7

Mycobank MB 341602

Basyonym - Parmelia isidiza Nylander. Boletim da Sociedad Broteriana Coimbra 3: 130. 1884.

Synonyms - Parmelia tiliacea var. hypoleuca Müller Argoviensis. Engler's Botanische Jahrbücher 20: 257. 1894.

Parmelia gillettii Dodge. Annals of the Missouri Botanical Garden 46: 86. 1959.

Holotype - Angola, Serra da Chella, Arraial de Cayonda, ad cortices arborum lecta praesertim in arbore Mopane dicta, leg. Newton s.n., V-1883, (H-Nyl!).

Thallus subirregular to sublinear sublaciniate, \pm pale dusky grey in herbarium, up to $12.4 \mathrm{~cm}$ in diam., submembranaceous, corticolous (rarely saxicolous or on manmade substrates), upper cortex 15.0-25.0 $\mu \mathrm{m}$ thick, algal layer $27.5-37.5 \mu \mathrm{m}$ thick, medulla 75.0-115.5 $\mu \mathrm{m}$ thick, lower cortex 15.0-22.5 $\mu \mathrm{m}$ thick. Laciniae irregularly to partially anisotomic dichotomously branched, 1.4-5.3 $\mathrm{mm}$ wide, slightly imbricate, adnate and tadpressed, with flat, subrotund apices, the margins flat, smooth to slightly sinuous, subcrenate or subirregular, entire, rarely sublacinulate, the axils oval. Upper cortex usually continuous with occasional irregular cracks, smooth to subrugose, laminal ciliar bulbs absent. Adventitious marginal lacinulae absent to scarce on random parts, short, 0.2$0.6 \times 0.1-0.4 \mathrm{~mm}$, plane, simple, apices truncate to subtruncate, lower side concolorous to the lower marginal zone. Maculae weak, moderate or distinct, punctiform, laminal or in the amphithecia of the apothecia. Cilia black to dark brown, apices simple to absent, often bent downwards, $0.05-0.10(-0.15) \times$ ca. $0.03 \mathrm{~mm}$, with semi- immerse to sessile bulbate bases ca. 0.05-0.10 $\mathrm{mm}$ wide, scarce to frequent and irregularly distributed along the margins but becoming frequent at the crenae and axils, spaced $0.5-0.20 \mathrm{~mm}$ from each other, usually absent or scarce on the apices of the laciniae.
Soredia and pustules absent. Isidia frequent, laminal, granular to smooth cylindrical, straight to slighty tortuous, $0.05-0.20(-0.30) \times$ $0.05-0.10(-0.15) \mathrm{mm}$, simple to sometimes sparsely branched, erect, occasionally firm but often caducous, concolorous and usually with brownish apices when developed, eciliate. Medulla white. Lower surface pale brown, except for veins or a few occasional slightly darker, randomly scattered parts, shiny, smooth, veined, moderately rhizinate. Marginal zone pale brown, indistinct or slightly darker than the center, shiny, smooth, sligthly rhizinate. Rhizines light to dark brown, sometimes whitish or with whitish apices, simple, without or partially with subtle blackish basal bulbs, $0.05-0.70 \times$ ca. $0.03-0.05$ $\mathrm{mm}$, frequent, becoming scarce when near to the margins, evenly distributed. Apothecia concave to subplane, adnate to substipiate, 0.3-3.6 $\mathrm{mm}$ in diam., laminal, ecoronate, margin smooth to subcrenate or subirregular and involute, amphithecia smooth eventually becoming isidiate, the isidia frequently larger and more branched than those found on the upper cortex. Disc brown to pale brown, epruinose, imperforate, epithecium 10.0-20.0 $\mu \mathrm{m}$ high, hymenium 35.0-57.5 $\mu \mathrm{m}$ high, subhymenium 15.0-22.5 $\mu \mathrm{m}$ high. Ascospores ellipsoid to oval, $10.0-16.0(-17.5) \times 5.0-9.0$ $\mu \mathrm{m}$, epispore $0.5-1.0 \mu \mathrm{m}$. Pycnidia not found (accordingly to Elix 1994 and Nash \& Elix 2002 , the conidia are bacilliform to weakly bifusiform, 5.0-6.0 × $1.0 \mu \mathrm{m})$.

TLC/HPLC - cortical atranorin and chloroatranorin, medullar salazinic and consalazinic acids (see also Hale 1976, Elix 1994, Nash \& Elix 2002).

Distribution - Oceania and North Pacific: Australia (Elix 1994), Fiji Islands (Elix 2001), Cook Islands, Rarotonga (Louwhoff \& Elix 2002), Hawaii (Hale 1976), Papua New Guinea (Streimann 1986, Elix 1994), Tahiti (Hale 1976). Asia: China (Wu et al. 1986), Philippines (Hale 1976), India (Hale 1976, Kumar \& Siquiera 2001, Divakar \& Upreti 2005), Indonesia (Hale 1976), Japan (Hale 1976), Malaysia (Hale 1976, Din et al. 2004), Nepal, (Hale 1976, Kurokawa 1993), Thailand (Wolseley \& Aguirre-Hudson 1997), Taiwan 
(Kurokawa \& Lai 2001). África: South Africa (Hale 1976), Angola (Dodge 1959, Hale 1976, Nylander 1884, Vainio 1901), Ivory Coast (Hale 1976), Ethiopia (Swinscow \& Krog 1988), Guinea, Malawi, Kenia, Tanzania, Uganda (Hale 1976, Swinscow \& Krog 1988, Krog 2000), Ruwanda (Killmann \& Fischer 2005, Bock et al. 2007), Tanzania (Müller Argoviensis 1894, as the synonym $P$. tiliacea var. hypoleuca) Somalia (Dodge 1959, as the synonym $P$. gillettii), Zaire, Zambia, Zimbabwe (former Rhodesia) (Dodge 1959, Hale 1976). North America: United States of America, (Dey 1987, Harris 1987, Brodo et al. 2001, Nash \& Elix 2002), Mexico (Hale 1976, Nash \& Elix 2002). Central America: Guatemala (Hale 1976). South America: Chile (Galloway \& Quilhot 1998), Paraguay (Hale 1976), Venezuela (López-Figueiras 1986, Marcano et al. 1996) and Brazil - Mato Grosso do Sul, (Fleig \& Riquelme 1991), Pará (Brako et al. 1985), Paraná (Eliasaro 2001), Rio de Janeiro (Hale 1976), Rio Grande do Sul (Fleig \& Grüninger 2000a, 2000b), and São Paulo (Hale 1976, Pereira \& Marcelli 1989, Marcelli 1990, 1993).

Additional selected specimens examined - Australia, Queensland, dividing range, few miles east of Atherton, E. Dahl s.n., 15-VII-1970 (MEL). Philippines, Luzon, Prov. Benguet, Mt. St. Tomas, exposed rocks near the road, 1560 m, leg. G. Degelius As-900, 18IV-1964 (US). India, Karnataka, HumchaSagar Road, thorn Forest-pasture, ca. 600 m, leg. M.E. Hale 48010, 01-III-1977 (US). Malaysia, Pahang, Robinsons Waterfall near Tanah Rata, leg. M.E. Hale 33702, 03-III-1965 (US). Somalia, Libah Mele Mt., 1675 m (5200 ft.), above Buja Soldan, $10^{\circ} 20^{\prime} \mathrm{N}, 43^{\circ} \mathrm{E}$, on twigs of Grewia sp.?, leg. J.B. Gillett 4699 pro parte, 3-XII-1932, (BM!, holotype of Parmelia gillettii). Tanzania, Ufipa, Chapota, $6500 \mathrm{ft}$., over roots of Polystachya on Brachystegia, leg. A.A. Bullock 2035 p.min.p., 11-XII-1949 (BM); idem, Usambara, auf Rinde, leg. Holst 787 pro parte (G!, lectotype of Parmelia tiliacea var. hypoleuca). Uganda, East Mengo, Bulemezi, near Kakinzi School, $0^{\circ} 57^{\circ} \mathrm{N}$, $32^{\circ} 28^{\prime} \mathrm{E}, 1100 \mathrm{~m}$, on lage tree branches, leg. K.A. Lye VS-41-04 L206, X-1969 (US). United States of America, Florida, Seminole
County, near Geneva, along Fla. 46, White sand scrub, on limbs of Pinus clausa, leg. B.J.Moore 2653, 26-XII-1965 (DUKE); idem, Hawaii, Maui, Puu Kukui, mossy Forest to alpine bog, 4300-5500 ft., trail from cabin to summit, leg. M.E. Hale 31247, VII-1965 (US). Mexico, Chiapas, $2 \mathrm{~km}$ north of highway 190 on road to Puebla Nueva, west of Chiapas, $1070 \mathrm{~m}$, pine pasture, on conifers, 23-III-1960, leg. M.E. Hale \& T.R. Soderstrom 20170 (US). Brazil, Pará, Serra do Cachimbo, $842 \mathrm{~km} N$ of Cuiabá on Mato Grosso on Cuiabá-Santarém highway (BR-163), ca. $8^{\circ} 45^{\prime} \mathrm{S}, 54^{\circ} 57^{\prime} \mathrm{W}$, ca. $350-500 \mathrm{~m}$, mature Forest along stream on sandy soil with deep humus and roadbank vegetation, on roadside Solanaceae, leg. Brako \& Dibben 6709, 5-V-1983 (NY); idem, São Paulo, Campo Limpo Paulista Municipality, on hillside near the Botujuru railway station, on tree trunk, leg. M.P. Marcelli \& A.E. Luchi 2888, 13-VI-1980 (SP); idem, Itirapina Municipality, Experimental Station (Pedregulho) at the Instituto Florestal, $780 \mathrm{~m}$ alt., $22^{\circ} 14^{\prime} 32^{\prime \prime}$ S, $47^{\circ} 49^{\prime} 48^{\prime \prime} \mathrm{W}$, on tree trunk in the open between pine and cerrado (savannah) vegetation, leg. L.S. Canêz, P. Jungbluth \& A.A. Spielmann 1214, 24-III-2004 (SP); idem, São Carlos Municipality, Universidade Federal de São Carlos (UFSCar) Campus, cerrado (savannah) area, $22^{\circ} 1$ ' S, $47^{\circ} 53^{\prime} \mathrm{W}$, alt. $855 \mathrm{~m}$, on small tree trunk near a firebreak, leg. M.N. Benatti \& G.G. Batista 2150, 4-IX-2006 (HUFSCAr); idem, São Paulo Municipality, Parque Estadual das Fontes do Ipiranga, Instituto de Botânica, on palm trunk, leg. M.P. Marcelli \& S.A.D. Andrade 34701, 24-VIII2000 (SP); idem, Serra Negra Municipality, Vale do Sol, near the km 12 of Serra NegraLindóia Highway, on ceramic tiles of the roofs of the cottages of the hotel, leg. M.P. Marcelli, O. Yano \& A.B. Carvalho 22996, 4-IV-1993 (SP).

Comments - The holotype (Fig. 5) is a small fragment not in a very good condition, glued to cardboard and severely damaged (it was necessary to remove part of the fragment from the card to observe the lower cortex). It contains two apothecia in good condition and a small part of a third apothecium, probably used by Nylander to study the hymenium and ascospores. The material contains several 
isidia, including in the apothecia. Ascospores are also in good condition.

Hale (1976), Swinscow \& Krog (1988) and Kurokawa \& Lai (2001) mentioned that it is particularly common in Africa, but as demonstrated here it is also frequent in the Neotropics. Hale (1976) also corrected that the specimen cited by Des Abbeys (1961) for Madagascar was actually of Parmelinella wallichiana (Taylor) Elix \& Hale.

The upper cortex of $B$. isidiza is usually rugose, somewhat different from other species in the genus, giving the thalli a rough appearance, as described by Nylander (1884), Hale (1976) and Ribeiro (1998). Besides the roughness of the upper cortex, all these authors also mentioned another easily observed feature in the specimens, including in the holotype, of the very delicate and small isidia. The apothecia are ecoronate, usually flat and adnate, like in all other Bulbothrix species with medullar salazinic acid.

Nylander (1884) did not notice the bulbate marginal cilia. He described the ascospores, which also appear on a label included with the type material as ellipsoid, 9.0-12.0 $\times$ 6.0-8.0 $\mu \mathrm{m}$, although those observed in the holotype are somewhat larger, $10.0-15.0 \times 5.0-9.0 \mu \mathrm{m}$. The larger spore dimensions were also cited by Kurokawa \& Lai (2001). Nash \& Elix (2002) and Hale (1976) described the ascospores as ellipsoid, 7.0-14.0 $\times 5.0-8.0 \mu \mathrm{m}$. Swinscow \& Krog (1988), Elix (1994) and Marcelli (1993) also described the ascospores as ellipsoid, but of slightly different dimensions, $10.0-16.0 \times 6.0-8.0 \mu \mathrm{m}$, and more in accordance to the general average sizes obsverved here. Ascospores 6.0-10.0 $\times$ 5.0-8.0 $\mu \mathrm{m}$ were found to be typical for $B$. subglandulifera (see below), once accepted as a synonym of $B$. isidiza by Hale (1976).

A few descriptions in the literature mention characters that cannot be considered typical. Contrary to that observed here, Dodge (1959) described specimens of $B$. isidiza with a black lower cortex as likely to be related to $B$. tabacina. The author noted marginal cilia, which he described as up to $1 \mathrm{~mm}$ long and spaced $1 \mathrm{~mm}$ from each other, but he did not mention the presence of basal bulbs. Swinscow \& Krog (1988) described B. isidiza specimens with very wide laciniae (1.2-10.0 mm wide), deeply divided, crenate and with truncate apices, with $1 \mathrm{~mm}$ long cilia. All other characters, however, fit quite well. Nash \& Elix (2002) mention isidia that are simple to coralloid in the specimens that they studied. This is somewhat unusual for the genus, but otherwise their description agrees well with the observations presented here. Divakar \& Upreti (2005) described the thalli as emaculate to weakly maculate, with simple to rarely coralloid, very tall isidia (up to $1.0 \mathrm{~mm}$ ). They mentioned rhizines also larger than normally found (1.0-1.5 mm long). Measurements of laciniae given in their key and in their description are contradictory: in the key they are given as $2.0-6.0(-10.0) \mathrm{mm}$ wide, in the description as $1.0-5.0 \mathrm{~mm}$ wide. Jungbluth (2006) also suggests that the cilia are longer $(1.25-1.8 \mathrm{~mm}$ ) and that the isidia are taller (up to $0.5 \mathrm{~mm}$ ) than can be confirmed here.

$$
\text { Eliasaro (2001) commented }
$$

sporadically finding norstictic acid in her material of $B$. isidiza and of B. hypocraea. This substance is unusual and it may only sporadically occur in the specimens, or could be ascribed to contamination of the specimens she examined. It cannot be confirmed for any specimen examined here, in no specimen the formation of the characteristic norstictic microcrystals could be observed nor was it possible to observe norstictic acid by TLC/HPLC. A label from Patricia Wolseley with the holotype of Parmelia gilletti Dodge also suggests that the material contains both norstictic and salazinic acids, but the specimen is morphologically indistinguishable from typical B. isidiza and both her report and that of Eliasaro of norstictic acid in the material cannot be confirmed here.

Hale (1976), Swinscow \& Krog (1988), Elix (1994), Kurokawa \& Lai (2001) and Divakar \& Upreti (2005) all mentioned that $B$. isidiza can be found corticolous as well as saxicolous. As seen from the material cited here, such indifference to the substrate must be considered fairly unusual for the genus Bulbothrix. Most species in the genus appear to be quite substrate specific. Nevertheless, Divakar \& Upreti (2005) also mention that $B$. isidiza is rarely found on soil. 
Hale (1976) suspected that $B$. hypocraea could be the parental form of $B$. isidiza, which is plausible given the morphological and chemical similarities of these two species. The presence of very conspicuous, punctiform maculae on most thalli, the ecoronate apothecia, the lower cortex colour, the colour and shape of the cilia and rhizines and the size of ascospores are all very similar.

Regarding the synonyms, Hale (1976) suggested that $P$. tiliacea var. hypoleuca Müller Argoviensis (1894), given by Dodge (1959) as a synonym of Parmelia lythogeana (= Hypotrachyna lythogeana), must actually be considered a synonym of $B$. isidiza instead. This is clearly a misunderstanding by Dodge. when he studied the type material of $P$. lythogeana, he might not have observed that this species is not isidiate. The type collection of P. tiliacea var. hypoleuca (Fig. 7) is poor, consisting of mixed thalli of two Bulbothrix species. One is a fragment containing few isidia and lacking apothecia; this specimen fragment is abundantly maculate, it belongs to Bulbothrix isidiza and this specimen was chosen here as the lectotype. The width of the laciniae in the lectotype specimen of $P$. tiliacea var. hypoleuca is half of the width typical of the holotype of $B$. isidiza, and it has more subcrenate margins with mainly axillary cilia. However, since this is only a very small specimen, and because the characters are overall very similar, this taxon is not considered a seperate species here. The other fragment in the packet of the type material is even smaller, much damaged, heavily parasitized, and it is uncertain to which species this fragment belongs. It has no maculae, it is paler, has partially bulbate cilia and does not have propagules or apothecia. Finally, this fragment contains norstictic acid unlike all other specimens examined here.

The holotype (Fig. 6) of Parmelia gillettii Dodge (1959) shows virtually no differences compard to the type material of $B$. isidiza. The main characteristics are all present, including the typical width of its laciniae, the cilia, the maculae, the lower cortex colour and venation, non-bulbate rhizines, and the size of ascospores. Dodge (1959) made no comments, and apparently he did not notice the cilia, because in his key $P$. gillettii is mentioned among the eciliate species. Dodge gives larger ascospores measurments in his key than those mentioned in the description $(18.5 \times 8.0 \mu \mathrm{m})$, and he calls the colour reaction in his key $\mathrm{K}+$ yellow to reddish orange, which is the colour reaction typically give for norstictic acid (the specimen does, however, contain salazinic acid, as confirmed here by HPLC). An annotation label of the holotype by Hale reads that he suspected that this specimen belongs to Parmelia sublaevigatoides, but Hale (1976) latter confirmed that $P$. gillettii should be considered a synonym of $B$. isidiza and instead $P$. sublaevigatoides is synonymous with $B$. tabacina.

Among the similar species, Bulbothrix tabacina Hale (L! lectotype, PC! duplicate) is the species most frequently compared to $B$. isidiza, differentiated only by the colour of the lower cortex, which is black with partially brown margins. The presence of consalazinic acid as a accessory substance was pointed out by Divakar \& Upreti (2005) as another difference.

Ribeiro (1998), Eliasaro (2001) and Jungbluth (2006) compared Bulbothrix ventricosa (TUR-V! lectotype) with $B$. isidiza. Bulbothrix ventricosa is distinguished by the variable colour of its lower cortex, more abundant cilia, coronate apothecia, frequent development of laminal ciliar bulbs, and by the presence of medullary norstictic acid (Benatti 2012a).

Saxicolous specimens of $B$. isidiza are similar to those of $B$. cinerea, due the laciniae aspect, isidiate thalli, simple cilia and rhizines and by the brown lower cortex. However, $B$. cinerea has a more greyish colour, generally larger isidia with darkened apices, rhizines often with bulbate bases, coronate apothecia and it contains norstictic acid in the medulla.

Bulbothrix australiensis (US! Holotype, MEL isotype n.v.) was compared to $B$. isidiza by Elix (1994). As seen, it differs by the narrower and sublinear laciniae $0.5-2.0 \mathrm{~mm}$ wide and by the emaculate upper cortex. The isidia of $B$. australiensis are usually much larger than those seen in specimens of $B$. isidiza, often up to $1.0 \mathrm{~mm}$ high. 
Bulbothrix subglandulifera (PC!, holotype) differs by much narrower laciniae $0.1-0.7 \mathrm{~mm}$ in width, frequently branched isidia, some with small basal bulbs, rhizines with distinct readily apparent basal bulbs and by the smaller ascospores, which usually measure 6.0-10.0 × 5.0-8.0 $\mu \mathrm{m}$ (see the detailed description that follows).

Bulbothrix microscopica Elix. Mycotaxon 47: 102. 1993.

Mycobank: MB 360108

Fig. 8

Holotype - Australia, Queensland, Tin Can Bay, along the foreshore of Tin Can Inlet, $25^{\circ} 54^{\prime} \mathrm{S}, 153^{\circ} 01^{\prime} \mathrm{E}, 1 \mathrm{~m}$ alt., strand vegetation, on Rhizophora stylosa, J.A. Elix 22862, 3-VII1989 (CANB!).

Thallus sublinear laciniate, dusky greenish grey in herbarium, up to $2.3 \mathrm{~cm}$ in diam., submembranaceous, corticolous, upper cortex 10.0-15.0 $\mu \mathrm{m}$ thick, algal layer 12.5-17.5 $\mu \mathrm{m}$ thick, medulla 25.0-32.5 $\mu \mathrm{m}$ thick, lower cortex 15.0-20.0 $\mu \mathrm{m}$ thick. Laciniae anisotomic dichotomously branched, $0.1-0.5(-0.7) \mathrm{mm}$ wide, contiguous, adnate and adpressed, with flat, truncate apices, the margins flat, smooth to sinuous, entire, not sublacinulate, the axils oval. Upper cortex smooth and continuous, laminal ciliar bulbs absent. Adventitious marginal lacinulae absent. Maculae absent. Cilia black, apices simple, often bent downwards, $0.05-0.25(-0.60) \times$ $0.02-0.03 \mathrm{~mm}$, with sessile bulbate bases $0.05-0.10 \mathrm{~mm}$ wide, frequent to abundant along the margins spaced ca. $0.05 \mathrm{~mm}$ from each other to contiguous, becoming absent or scarce at the apices of the laciniae. Soredia and pustules absent. Isidia frequent to abundant, laminal, granular to smooth cylindrical, straight, $0.05-0.15(-0.25) \times$ ca. $0.05 \mathrm{~mm}$, simple, erect, firm, concolorous or with brownish apices, eciliate. Medulla white. Lower cortex dark brown, shiny, smooth, moderately rhizinate. Marginally brown, paler than in the center, attenuated, $0.2-0.7 \mathrm{~mm}$ wide, shiny, smooth, weakly rhizinate. Rhizines dark brown to black, simple, usually without basal or displaced bulbs (some few appear to have subtle bulbs), $0.10-0.30 \times$ ca. $0.03 \mathrm{~mm}$, frequent, usually sparse leaving the lower cortex visible but occasionally more dense at a few random parts, \pm evenly distributed. Apothecia and pycnidia not found.

TLC/HPLC - cortical atranorin and chloroatranorin, medullar salazinic and consalazinic acids (see also Elix 1993b, 1994).

Distribution - Oceania: Australia (Elix 1993b, 1994).

Comments - The holotype (Fig. 8) consists of a small thallus that is almost intact, in excellent condition. It adheres to tree bark, which is glued to cardboard and for this study it was necessary to remove part of it from the substrate to determine the colour of the lower cortex; the piece removed was subsequently glued back onto the cardboard, along the thallus to facilitate that other researchers can examine the cortex more easily. Apothecia, ascospores and conidia are still unknown for the species.

Bulbothrix microscopica is one of the smallest species of the genus, with very narrow laciniae, unlikely to exceed $0.5 \mathrm{~mm}$ wide. All features observed in the holotype are in agreement with the descriptions of Elix (1993b, 1994), except for the colour of the lower cortex, described as black, but which is actually dark brown, with margins paler than the center. Due to the narrow space between the internodes of the laciniae and to the narrow size of these, the cilia, that are in reality axillary, as commonly occurs in Bulbothrix species with medullary salazinic acid, eventually cover almost the entire margin with the exception only of the apices of the laciniae.

Elix (1993b, 1994) compared $B$. microscopica to $B$. subtabacina (MEL! holotype, CANB! isotype). As seen here, this species differs by wider laciniae (ca. 0.5-1.5 $\mathrm{mm}$ ), strongly cracked and maculate upper cortex, ciliate isidia, crenate margins, branched cilia and rhizines and by the almost uniformly black lower cortex.

Among the larger similar species, Bulbothrix tabacina (L! lectotype, PC! duplicate) differs by wider, subirregular laciniae $(1.5-5.5 \mathrm{~mm})$ with rounded apices and crenate margins, maculate upper cortex, and by a black lower cortex with brown margins. Bulbothrix isidiza (H-Nyl! holotype) also differs by wider subirregular laciniae (2.0-5.5 $\mathrm{mm}$ ) with rounded apices, rugose and maculate 

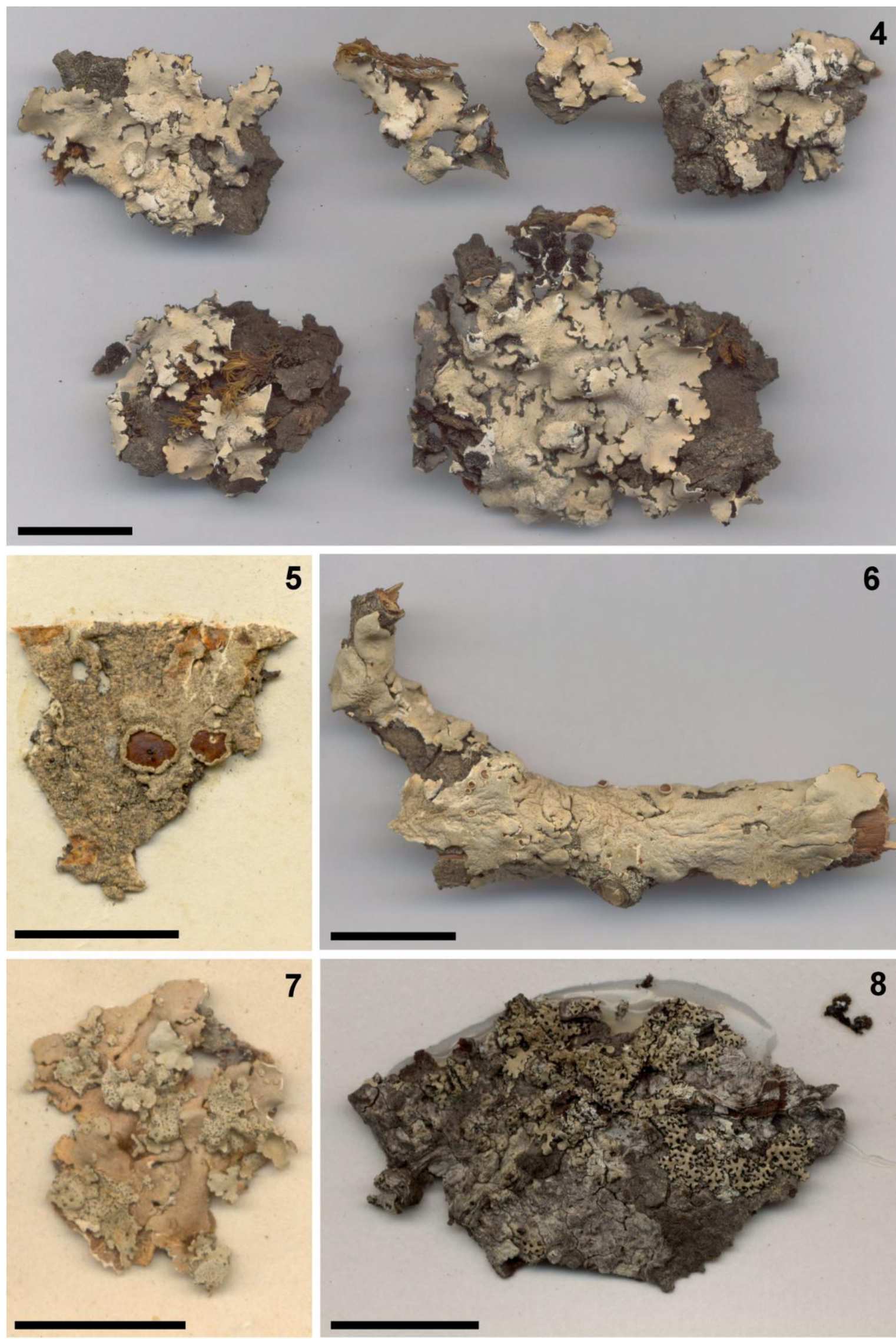

Figs 4-11 - 4 Holotype of Bulbothrix imshaugii (MSC). 5 Holotype of Bulbothrix isidiza (H-Nyl). 6 Holotype of Parmelia gillettii (BM). 7 Holotype of Parmelia tiliacea var. hypoleuca (G). 8 Holotype of Bulbothrix microscopica (CANB). Scale bars $=1 \mathrm{~cm}(4,5,6,7,8)$. 
upper cortex, and by a light brown lower cortex with brown rhizines.

Most closely related is another small species, Bulbothrix australiensis (US! Holotype, MEL isotype n.v.) which has slightly wider sublinear laciniae $(0.5-2.0 \mathrm{~mm})$, elongated and eventually branched isidia that are often more than $1.0 \mathrm{~mm}$ tall; it also has a pale brown lower cortex and rhizines with dark basal bulbs. Bulbothrix linteolocarpa Marcelli (SP!, holotype) is also similar to $B$. microscopica due its narrow laciniae (ca. 0.2-0.5 mm wide), emaculate upper cortex, sinuous and frequently ciliate margins, and medullar salazinic acid. However, unlike $B$. microscopica, it is not isidiate, and its cilia and rhizines vary from simple to furcate, the rhizines always developing from basal bulbs.

Bulbothrix pustulata (Hale) Hale. Phytologia 28(5): 480. 1974. Figs 9-10.

Mycobank MB 341608

Basyonym - Parmelia pustulata Hale. Contributions from the United States National Herbarium 43: 140. 1964.

Holotype - Burundi, Ngozi, bamboothickets, $2100 \mathrm{~m}$, on bamboo, leg. Deuse s.n. (US!, isotypes at $\mathrm{LG}$ and $\mathrm{O} \mathrm{nv}$.).

Thallus subirregular sublaciniate, dusky grey in herbarium, fragments up to $9.3 \mathrm{~cm}$ in diam., fragile membranaceous, corticolous, upper cortex 7.5-12.5 $\mu \mathrm{m}$ thick, algal layer 20.0-32.5 $\mu \mathrm{m}$ thick, medulla $100.0-125.0 \mu \mathrm{m}$ thick, lower cortex 5.0-10.0 $\mu \mathrm{m}$ thick. Laciniae irregularly to occasionally \pm anisotomic dichotomously branched, (1.5-) 2.6-5.5 $\mathrm{mm}$ wide, imbricate becoming crowded at the center, weakly adnate and loosely adpressed, with flat, subrotund to subtruncate apices, the margins flat, smooth to crenate or occasionally irregular, entire to slightly incised, not sublacinulate, the axils oval to irregular. Upper cortex smooth to subrugose, usually with many irregular cracks that eventually become more accentuated at the older parts, sometimes flaking off the cortex, laminal ciliar bulbs absent. Adventitious marginal lacinulae absent. Maculae absent. Cilia black, apices simple or occasionally double, and short and curved, 0.05-0.25 ($0.40) \times$ ca. $0.03 \mathrm{~mm}$, with sessile bulbate bases ca. $0.10(-0.15) \mathrm{mm}$ wide, scarce along the margins becoming frequent at the crenae and axils spaced ca. $0.05-0.10 \mathrm{~mm}$ from each other, solitary or in small groups becoming absent at the apices and adjacent parts of the laciniae. Soredia and isidia absent. Pustules in the form of irregular wrinkles or twisted and villous dactyloid structures, laminal, intact or erumpent, sometimes disintegrating into coarse granules. Medulla white. Lower cortex black, with random dark brown spots at the transition for the center, shiny, smooth to subrugose, weakly papillate, moderately rhizinate. Marginal zone brown, attenuated, ca. 1.0-6.0 $\mathrm{mm}$ wide, shiny, smooth to subrugose, papillate becoming rhizinate in the ransition for the center. Rhizines black, simple to occasionally furcate, without basal or displaced bulbs, $\quad 0.10-0.40 \times$ ca. $0.04 \mathrm{~mm}$, usually frequent but scarcer when near the margins, evenly distributed. Apothecia concave, adnate, 0.3-1.7 $\mathrm{mm}$ in diam., laminal, ecoronate, margin smooth, amphithecia initially smooth becoming subrugose and pustulate. Disc brown, epruinose, imperforate, epithecium 10.0-12.5 $\mu \mathrm{m}$ high, hymenium $37.5-55.5 \mu \mathrm{m}$ high, subhymenium 25.0-30.0 $\mu \mathrm{m}$ high. Ascospores ellipsoid to oval, 9.0-14.0 $\times$ 6.0-8.0 $\mu \mathrm{m}$, epispore ca. $1.0 \mu \mathrm{m}$. Pycnidia not found.

TLC/HPLC - cortical atranorin, medullar salazinic acid (see also Hale \& Kurokawa 1964, Hale 1976, Sérusiaux 1984).

Distribution - Africa: Burundi (Hale \& Kurokawa 1964, Hale 1976, Sérusiaux 1984), Rwanda (Sérusiaux 1984, Bock et al. 2007), Tanzania (Krog 2000).

Comments - The holotype (Fig. 9) is fragmented, with various parts heavily damaged, but overall nevertheless reasonably preserved. Several sections of the margins and apices of laciniae are so damaged that it is difficult to find any bulbate cilia, although these are present. Despite the poor condition of the material, the pustules are easily noticed.

Although not cited in the protologue of the species, Sérusiaux (1984) mentioned three isotypes, one in $\mathrm{LG}$, the other in $\mathrm{O}$, and another in the Follmann herbarium, those unfortunately could not be located or obtained on loan. According to Sérusiaux (1984), the type 
material of $B$. pustulata was collected in 1958 by $P$. Deuse, a Belgian botanist working in Rwanda and Burundi. The chemistry was studied by Ramaut (1965 in Sérusiaux 1984), and the material sent to M.E. Hale. Sérusiaux (1984) mentioned that the collection at LG was large and that the material was divided into isotypes, subsequently sent to the $\mathrm{O}$ and Follmann herbaria, though Hale (1964) and Hale \& Kurokawa (1976) did not make any mention of isotypes, perhaps unaware of their existence. Hale concluded that the species should be really rare, noting that J. Lambinon, who collected much in the region, found only one other poor specimen, and a few kilometers from the type locality, on the same substrate: bamboo stalks in secondary woods inside forests in mountainous regions.

This is one of the only two Bulbothrix species which are known to form pustules, the other being B. oliveirae A. Fletcher. Agreeing with general observances of Hale \& Kurokawa (1964), Hale (1976) and Sérusiaux (1984), the thallus of $B$. pustulata is membranaceous, brittle and rough, with the upper cortex easily flaking off, the irregular subrotund laciniae has wide inconspicuously ciliate crenae, and the inflated pustules have an irregular appearance or are sometimes similar to isidioid dactyls, breaking apically, but not forming true soredia (Fig. 10).

Hale \& Kurokawa (1964) did not mention apothecia on the original description, but latter Hale (1976) mentioned rudimentary sessile apothecia, up to $1.5 \mathrm{~mm}$ in diam., however he did not find ascospores. Sérusiaux (1984) mentioned some adnate apothecia, up to $2 \mathrm{~mm}$ in diam., for the LG isotype, with eroded margins and brown discs, containing ellipsoid ascospores $14.0-16.0 \times 8.0$ to $9.0 \mu \mathrm{m}$. The apothecia in the holotype are few in number, but the more developed ones contain asci with mature ascospores. As seen, the size of the ascospores are slightly smaller than those mentioned by Sérusiaux (1984) and similar to those of $B$. tabacina, which looks like $B$. pustulata in morphology and chemistry, and with that it must somehow be related, as supposed by Hale (1976). There are no pycnidia in the holotype of $B$. pustulata.
Sérusiaux (1984) referred to the pustules of $B$. pustulata as dactyls in the sense of Swinscow \& Krog (1978). However, the publication by Swinscow \& Krog (1978) focuses on Dirinaria (Tuck.) Clem. a genus in the Physciaceae and the structures observed in Parmeliaceae may in fact not be identical to those of the Physciaceae. Here, the term "dactyls" as used by Swinscow \& Krog (1988) is considered inappropriate for structures observed in B. pustulata. The term pustule appears more adequate because these structures do not fit well the definition of "a nodular to cylindrical to clavate body, somewhat resembling a swollen isidium...".

Among other large laciniate Bulbothrix species containing medullary salazinic acid, $B$. tabacina (L! lectotype, PC! duplicate) was compared to B. pustulata by Hale \& Kurokawa (1964), and as seen it differs by the continuous, smooth and maculate cortex, and by the formation of simple laminal isidia rather than pustules. Bulbothrix meizospora (Nyl.) Hale (H-Nyl! holotype) differs by the absence of pustules or vegetative propagation, and by the larger ascospores 12.0-22.0 × 9.0-12.0 $\mu \mathrm{m}$. Bulbothrix isidiza (H-Nyl! holotype) differs by the maculate subrugose cortex, by the formation of simple or sparsely branched small isidia, and by the pale brown lower cortex with brown rhizines. Bulbothrix hypocraea (TUR$\mathrm{V}$ ! lectotype, BM! duplicate) differs by the smooth and maculate upper cortex, light brown lower cortex with brown, bulbate rhizines, and by the absence of vegetative propagules or pustules.

As previously stated, Bulbothrix oliveirae (NY!, holotype) is the only other species in the genus that form pustules. It differs from $B$. pustulata by more narrow, sublinear laciniae (ca. $0.5-1.0 \mathrm{~mm}$ wide), smooth upper cortex, dichotomously branched cilia and rhizines, and by the presence of medullary gyrophoric acid as main substance. In direct comparison, the pustules of $B$. oliveirae are more rounded, like smooth "bubbles" or "pellets". When these "pellets" break off, the thallus becomes deeply eroded exposing thus even its lower cortex, which in turn appears covered by granules, fragments 
derived from the breakdown of the cortex due to the erosion of the "pellets". In B. pustulata these structures are more "uplifted", occasionally resembling very rough and retorted actyls. They are in fact are similar to those seen in specimens of Parmotrema madilynae Fletcher and thalli of $B$. pustulata may resemble to some extend very small thalli of $P$. madylinae, even though this species has bulbate cilia and contains different medullary substances. Unlike the pustules of $B$. oliveirae, those of $B$. pustulata do not erode quite as deeply, thus not leaving the cortex lower exposed.

\section{Bulbothrix subglandulifera (Hue) Hale.} Phytologia 28(5): 481. $1974 . \quad$ Fig. 11 Mycobank MB 341616

Basionym - Parmelia subglandulifera Hue. Nouvelles Archives du Muséum Paris, série 3(1): 144. 1899. Holotype: Madagascar, in littore occidental, corticolam, leg. Grandidier s.n. (PC!).

Thallus sublinear laciniate, pale dusky grey in herbarium, up to $2.5 \mathrm{~cm}$ in diam., subcoriaceous, corticicolous, upper cortex 17.5-22.5 $\mu \mathrm{m}$ thick, algal layer $20.0-32.5 \mu \mathrm{m}$ thick, medulla 95.5-120.0 $\mu \mathrm{m}$ thick, lower cortex 17.5-20.0 $\mu \mathrm{m}$ thick. Laciniae anisotomic dichotomously to irregularly branched, contiguous to slightly imbricate, 0.4-1.3 (-1.9) mm wide, adnate and adpressed, with flat, subtruncate to truncate apices, the margins flat, slightly sinuous to crenate or subirregular, entire to slightly incised, occasionally sublacinulate, the axils oval or irregular. Upper cortex smooth and continuous, occasionally with a few irregularly cracks, laminal ciliar bulbs absent. Adventitious marginal lacinulae scarce on random parts, short, $0.2-0.8 \times 0.1-0.2 \mathrm{~mm}$, plane, simple to irregularly branched, apices truncate or acute, lower side concolorous to the lower marginal zone. Maculae weak to distinct, punctiform, laminal. Cilia black to brown, apices simple or absent, $0.05-0.40 \times$ ca. $0.03-0.05 \mathrm{~mm}$, with sessile bulbate bases $0.05-0.20 \mathrm{~mm}$ wide, frequent along the margins but more abundant at the crenae and axils spaced ca. $0.05 \mathrm{~mm}$ from each other eventually becoming contiguous, solitary or in small groups becoming absent or scarce at the apices of the laciniae. Soredia and pustules absent. Isidia abundant, laminal, granular to smooth cylindrical, straight to slightly tortuous, $0.05-0.30 \times$ ca. $0.05 \mathrm{~mm}$, simple to often branched, erect to procumbent, firm to caducous, concolorous or with brownish apices, partially ciliate with small bulbs. Medulla white. Lower surface pale brown, sometimes slightly darker at a few random parts, shiny, smooth to subrugose, weakly to moderately rhizinate. Marginal zone brown indistinct from the center to sometimes slightly darker, shiny, smooth, weakly rhizinate. Rhizines pale to dark brown, simple, usually with bulbate bases, $0.10-0.70 \times 0.03-0.05 \mathrm{~mm}$, frequent becoming scarcer near the margins, evenly distributed. Apothecia concave, adnate to subpedicellate, $0.3-2.6 \mathrm{~mm}$ in diam., laminal, ecoronate, margin subcrenate to revolute, amphitecia smooth sometimes becoming weakly isidiate. Disc dark brown, epruinose, imperforate, epithecium 10.0-15.0 $\mu \mathrm{m}$ high, hymenium 60.0-75.0 $\mu \mathrm{m}$ high, subhymenium 40.0-50.0 $\mu \mathrm{m}$ high. Ascospores rounded to ellipsoid or oval, 6.0-10.0 (-11.0) $\times 5.0-7.0(-8.0) \mu \mathrm{m}$, epispore $0.5-1.0(-1.5)$ $\mu \mathrm{m}$. Pycnidia laminal, scarcet, immerse, with black ostioles. Conidia bacilliform to weakly bifusiform 5.0-7.0 $\times$ ca. $0.75 \mu \mathrm{m}$.

TLC/HPLC - cortical atranorin, medullary salazinic acid (see also Hale 1976). (Hue 1899).

Distribution - Africa: Madagascar

Additional specimen examined Madagascar, côte ouest, leg. Grandidier s.n. (PC).

Comments - The holotype (Fig. 11) is a much fragmented thallus on pieces of bark. It is reasonably preserved, although several parts of the laciniae are damaged, and the medulla is stained by oxidized salazinic acid. There is a large amount of isidia covering parts of the cortex, and some apothecia in good condition containing mature ascospores. The material has only a few pycnidia, nevertheless these contain conidia.

Hue (1899) mentions that $B$. subglandulifera can be characterized by isidia that eventually became soredioid. The material studied here shows granular isidia with some 

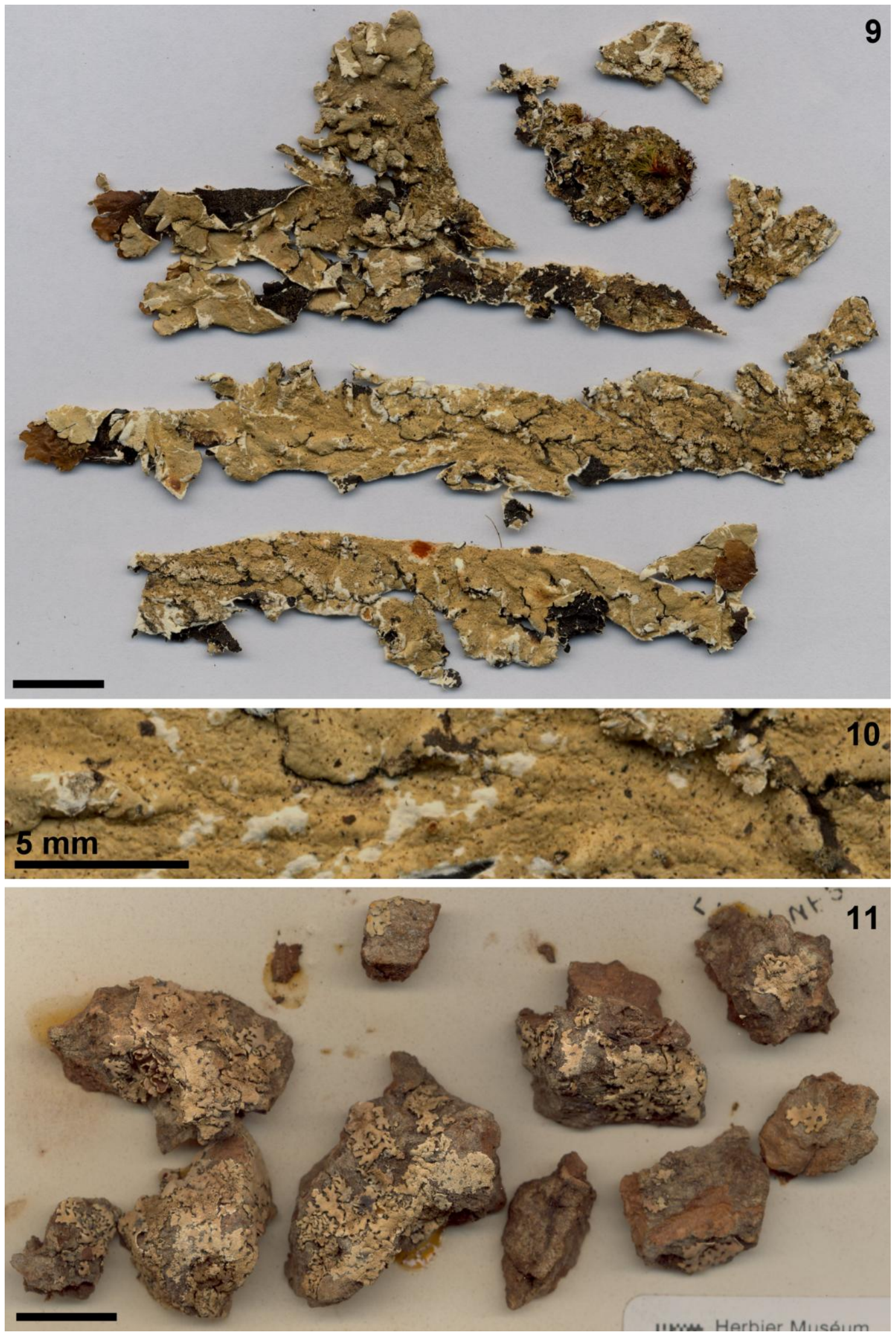

Figs 9-11 - Holotype of Bulbothrix pustulata (US). 10 Detail of the upper cortex of the holotype. 11 Holotype of Bulbothrix subglandulifera $(\mathrm{PC})$. Scale bars $=1 \mathrm{~cm}(9,10)$, and $5 \mathrm{~mm}(11)$. 
similarity to soredia, but these are nevertheless young and still poorly developed true isidia and even the largest isidia always remain corticate; they do not become sorediate. The "marginal dark glands" mentioned by Hue (1899) are in fact bulbate bases of cilia, which have not yet apically differentiated into distinct cilia. Contrary to what Hue (1899) observed the unusually large measurments of the laciniae can also not be confirmed here, as he gave measurements approximately three times the width seen here.

The species was treated as a synonym of B. isidiza by Hale (1976). However, among the synonyms, it is unique in having ascospores usually smaller than $10 \mu \mathrm{m}$ (quite uncommon for the salazinic group), besides other apparently constant differences. Bulbothrix isidiza (H-Nyl! holotype) differs by the wider subirregular laciniae (ca. $1.5-5.0 \mathrm{~mm}$ wide) with rounded apices, generally simple isidia, rhizines without bulbate bases, and larger ascospores, usually $11.0-16.0 \times 5.0-9.0 \mu \mathrm{m}$.

Among other species, Bulbothrix australiensis is somewhat similar to $B$. subglandulifera, however differs by the emaculate thallus, usually simple and larger isidia (0.5-1.0 $\mathrm{mm}$ high), and by the darker brown colour of the lower cortex. Bulbothrix cinerea (Kalb pers. herb!, holotype) has a similar pale brown lower cortex and rhizines with dark bulbate bases, but differs by its saxicolous habit, coriaceous, dark and emaculate thallus, generally simple (sometimes dilated or lobulated) isidia, the ascospores $10.0-14.0 \times 6.0-8.5 \mu \mathrm{m}$, and by the presence of medullary norstictic acid.

Bulbotrix subscortea (Asahina) Marcelli \& Benatti. Mycosphere 3(1): 48. 2012.

Mycobank MB 519638

Basionym - Parmelia subscortea Asahina. Journal of Japanese Botany 32: 99. 1957.

Holotype - Taiwan, Keitau, saxicolous, leg. Y. Asahina 3324, 24-XII-1933 (TNS!).

For image see Benatti (2012b)

Bulbothrix subscortea is characterized by the broad (ca. 1.0-5.5 mm wide) subirregular laciniae, emaculate upper cortex, frequent marginal cilia with simple apices, simple to slightly branched isidia, an usually pale brown lower cortex, brown simple rhizines with basal or displaced bulbs, and by the presence of medullary salazinic acid. For description and comments on this species and some other recent combinations, see Benatti 2012 b.

\section{Bulbothrix subtabacina (Elix) Elix.}

Mycotaxon 47: 127. 1993. Fig. 12

MB 360133

Basionym - Parmelia subtabacina Elix. Australian Journal of Botany 27: 875. 1979.

Holotype - On tree in pocket of rainforest, Long Beach, $3 \mathrm{~km}$ east of Batemans Bay, New South Wales, Australia, 3542'S, $150^{\circ} 13^{\prime}$ E, alt. 6 m., 19-III-1977, leg. J.A. Elix 2951 (MEL!, isotype at CANB!).

Thallus sublinear laciniate, dark dusky greenish grey in herbarium, up to $4.5 \mathrm{~cm}$ in diam., submembranaceous, corticolous, upper cortex 7.5-10.0 $\mu \mathrm{m}$ thick, algal layer 10.0-15.0 $\mu \mathrm{m}$ thick, medulla 32.5-50.0 $\mu \mathrm{m}$ thick, lower cortex 5.0-7.5 $\mu \mathrm{m}$ thick. Laciniae anisotomic dichotomously to tirregularly branched, contiguous to slightly imbricate, 0.4-1.1 (-1.5) mm wide, adnate and adpressed, with subplane, subtruncate to truncate apices, the margins flat, smooth and sinuous to partially subirregular, entire to slightly incised, occasionally sublacinulate, the axils oval or irregular. Upper cortex smooth, almost entirely irregularly cracked (most commmon at the center) except by the distal parts, laminal ciliar bulbs absent. Adventitious marginal lacinulae scarce and occasional, short, $0.2-0.3 \times$ ca. 0.1 $\mathrm{mm}$, plane, simple, apices truncate, lower side concolorous with the lower marginal zone. Maculae weak to distinct, easily visible at the distal parts, punctiform, laminal. Cilia black to brown, apices initially simple becoming furcate and finally dichotomously branched, $0.05-0.25$ $\times$ ca. $0.03-0.04 \mathrm{~mm}$, with semi-immerse to sessile bulbate bases $0.05-0.10 \mathrm{~mm}$ wide, abundant along the margins spaced $0.05-0.10$ $\mathrm{mm}$ from each other, becoming absent or scarce at the apices of the laciniae. Soredia and Pustulespustules absent (parts where there are much detachment of isidia expose the medulla in a way similar to that of rudimentary soralia). Isidia abundant, laminal, granular or smooth cylindrical, straight to tortuous, $0.05-0.15$ 
$(-0.25) \times$ ca. $0.05 \mathrm{~mm}$, simple to slightly branched, occasionally aggregate, erect, firm to caducous, concolorous to the upper cortex, commonly ciliate. Medulla white. Lower surface black, with small dark brown spots, shiny, smooth, moderately rhizinate. Marginal zone variable, black and indistinct from the center to brown and attenuated $0.5-1.5 \mathrm{~mm}$ wide, shiny, smooth, rhizinate. Rhizines black, initially simple soon becoming furcate and then dichotomously or irregularly branched, without bulbate bases (some have a slight swelling, but it is uncertain if that are very subtle bulbs), $0.10-0.50 \times$ ca. $0.03 \mathrm{~mm}, \pm$ sparse leaving the lower cortex visible, evenly distributed. Apothecia and pycnidia not found.

TLC/HPLC - cortical atranorin and chloroatranorin, medullary salazinic acid (see also Elix \& Stevens 1979, Elix 1994).

Distribution - Oceania: Australia (Elix \& Stevens 1979, Elix 1993b, Elix 1994).

Comments - The holotype (Fig. 12) of this species consists of a thallus that is still almost completely intact; additionally the packet also contains a small fragment, also of excellent condition. Both specimens are glued to cardboard (it was necessary to remove a part from the substrate to study its lower cortex). No apothecia or pycnidia could be found on either one of the thalli. The isotype, obviously not a fragment of the holotype, seems to be instead a complete small thallus, maybe collected together. It is slightly less cracked than the holotype specimen, although its center appears just as fragmented. Like the holotype, the isotype lacks apothecia and pycnidia, but it is much more isidiate.

As described by Elix \& Stevens (1979) and Elix (1994), the thalli present a very frequent cracked upper cortex, more than commonly seen for other species of the genus, the center so fissured as looking areolate in some parts. The eroded parts that the authors have referred are the result of the combination of cracks with the strong marks left by blocks of detached isidia.

The species is maculate, but it is difficult to see in the material examined, due to the large amount of isidia on the upper cortex, and the numerous marks left when they break off. The marks are so abundant in some parts that they end up masking the true maculae. Because of this, the maculae are often more easily seen in the distal portions of the laciniae, where isidia are few or absent.

The isidia apparently detach in large quantities as small blocks, leaving deep marks in the upper cortex, essentially causing the thallus to be covered in small holes. Eventually, these marks are large enough to expose medullary hyphae, in appearance somewhat similar to pseudocyphellae seen in Punctelia species but also resembling eroded soralia (true soredia, however, were not seen in any part). The isidia of $B$. subtabacina are similar to those seen in the holotype of $B$. fungicola (S!) because they are generally simple and short, often only small ciliar bulbs that have not yet developed into cilia can be observed.

Usually, Bulbothrix species containing medullary salazinic acid such as $B$. hypocraea (TUR-V! lectotype, BM! duplicate), $B$. isidiza (H-Nyl! holotype), B. meizospora (Nylander) Hale (H-Nyl! holotype) or B. tabacina (L! lectotype, PC! duplicate) have much wider laciniae (usually three or four times the width of those from B. subtabacina) with a more irregular branching pattern and rounded apices. Curiously, the overall aspect of $B$. subtabacina resemble those containing medullary gyrophoric, lecanoric or lobaric acids.

Bulbothrix tabacina was compared to B. subtabacina by Elix \& Stevens (1979). It differs by wider laciniae $(1.5-5.5 \mathrm{~mm}$ wide) with rounded apices, a continuous upper cortex, eciliate isidia, and by the usually simple cilia and rhizines. Elix (1994) also compared $B$. subtabacina to B. microscopica (CANB!, holotype), which differs by the narrower, halfsize laciniae (0.1-0.5 mm wide), emaculate upper cortex, and by the simple cilia and rhizines.

Bulbothrix tabacina (Montagne \& Bosch) Hale. Phytologia 28:481. 1974. Fig. 13-16 MB 341619

Basionym - Parmelia tabacina Montagne \& Bosch. Sylloge generum specierumque cryptogamarum: 327. 1856.

Synonyms - Parmelia meizospora var. isidiosa Müller Argoviensis. Flora 67: 620. 


\section{4 (nomem nudum).}

Parmelia meizosporoides Dodge. Annals of the Missouri Botanical Garden 46: 83. 1959.

Parmelia ochrovestita Zahlbruckner. Annales de Cryptogamie Exotique. 1: 200. 1928.

Parmelia sublaevigatoides Dodge. Annals of the Missouri Botanical Garden 46: 88. 1959.

Lectotype: Indonesia, Java, in cortice arborum, leg. Junghuhn s.n. (L!, isolectotype at PC!).

Thallus sublinear to subirregular laciniate to sublaciniate, pale grey to dusky greenish grey in herbarium, up to $7.3 \mathrm{~cm}$ in diam., submembranaceous to subcoriaceous, corticolous or rarely saxicolous, upper cortex $10.0-15.0 \mu \mathrm{m}$ thick, algal layer $12.5-20.0 \mu \mathrm{m}$ thick, medulla 45.0-100.0 $\mu \mathrm{m}$ thick, lower cortex 10.0-12.5 $\mu \mathrm{m}$ thick. Laciniae irregularly to partially anisotomic dichotomously branched, (0.6-) 1.6-4.1 (-5.4) mm wide, contiguous to imbricate becoming partially crowded at the center, slightly adnate and adpressed, with flat, subrotund to subtruncate or rarely truncate apices, the margins flat, smooth and sinuous to crenate or subirregular, entire to slightly incised, occasionally sublacinulate, the axils oval or irregular. Upper cortex smooth and continuous, occasionally subrugose with variable irregular cracks on older parts, laminal ciliar bulbs absent. Adventitious marginal lacinulae absent to scarce on random parts, short, $0.2-1.3 \times 0.1-$ $0.4 \mathrm{~mm}$, plane, simple to irregularly branched, apices truncate, lower side concolorous to the lower marginal zone. Maculae weak to distinct, punctiform, laminal. Cilia black to occasionally brown, apices simple to rarely double, occasionally bent downwards, $0.05-0.30$ $(-0.40) \times 0.03-0.04 \mathrm{~mm}$, with semi-immersed to sessile bulbate bases ca. $0.05-0.15(-0.20)$ $\mathrm{mm}$ wide, scarce to frequent along the margins spaced $0.5-0.10(-0.15) \mathrm{mm}$ from each other to rarely contiguous, solitary or in small groups in the crenae and axils, usually absent or scarce on the apices of the laciniae. Soredia and pustules absent. Isidia frequent, laminal, usually breaking off together in small packets, smooth, cylindrical or rarely granular, straight to tortuous, $0.05-0.60 \times \mathrm{ca}$. $0.05(-0.15) \mathrm{mm}$, simple to sometimes sparsely branched, erect to procumbent, firm to caducous, concolorous with the upper cortex, brownish or with brownish apices, eciliate. Medulla white. Lower surface black, with some occasional small dark brown spots in the transition area to the margins (these spots rarely more extensive, stretching between the margin and center), slightly shiny to opaque, smooth to subrugose, venate, weakly papillate, moderately rhizinate. Marginal zone pale to dark brown and attenuated, 1.0-3.0 (-6.0) $\mathrm{mm}$ wide, rarely black and indistinct from the center, shiny, smooth to subrugose, papillate becoming rhizinate in the transition to the center. Rhizines black, pale to dark brown or with whitish apices when near the margins, simple to rarely irregularly branched, without basal or displaced bulbs, $0.10-0.70 \times$ ca. $0.03-0.05$ $\mathrm{mm}$, frequent, often scarce near the margins, but somewhat randomly scattered and in some parts abundant, often appearing from venations and warts, \pm evenly distributed. Apothecia subplane to concave or urceolate, adnate to substipiate, $0.3-5.2 \mathrm{~mm}$ in diam., laminal to submarginal, ecoronate, margin smooth to subrugose and subcrenate, amphithecia smooth to subrugose eventually becoming isidiate. Disc pale to dark brown, epruinose, imperforate, epithecium 5.0-7.5 $\mu \mathrm{m}$ high, hymenium $35.0-50.0 \mu \mathrm{m}$ high, subhymenium 25.0-30.0 $\mu \mathrm{m}$ high. Ascospores ellipsoid to oval, 9.0-15.0 $(-16.5) \times 5.0-8.0(-10.0) \mu \mathrm{m}$, epispore $0.5-1.5(-2.0) \mu \mathrm{m}$. Pycnidia scarce, laminal to submarginal, on central parts of the thalli, with brown to black ostioles. Conidia (not found on the type) weakly bifusiform, 4.0-6.0 × ca. $1,0 \mu \mathrm{m}$.

TLC/HPLC - cortical atranorin, medullary salazinic acid (see also Hale 1976; there are also labels of Kurokawa dated 1960 and Aptroot dated 1985 together with the type material). The holotype of $P$. meizosporoides also contain cortical chloroatranorine and medullary consalazinic acid, with traces of norstictic acid (this last one possibly a contaminant).

Distribution - Oceania: Australia (Hale 1976, Elix 1994), Polynesia (Louwhoff \& Elix 2000), Rarotonga (Louwhoff \& Elix 2002a). 
Asia: India (Hale 1976, Divakar \& Upreti 2005), Indonesia (Zahlbruckner 1928, as the synonym Parmelia ochrovestita, Junghuhn 1855, Montagne 1856, Hale 1976), Philippines (Hale 1976), Malaysia (Hale 1976), Nepal, (Hale 1976, Kurokawa 1993), Sri Lanka (Awasthi 1976), Taiwan (Hale 1976, Kurokawa \& Lai 2001). Africa: Angola (Hale 1976), Congo (Dodge 1959, as the synonym $P$. sublaevigatoides), Ethiopia (Swinscow \& Krog 1988), Guinea (Hale 1976), Madagascar (Dodge 1959, as the synonym $P$. meizosporoides, Hale 1976, Aptroot 1990), Malawi, Mozambique, South Africa (Dodge 1959, as the synonym P. sublaevigatoides), Kenia (Swinscow \& Krog 1988), Uganda (Dodge 1959, as the synonym $P$. sublaevigatoides, Swinscow \& Krog 1988), Tanzania (Dodge 1959, as the synonym $P$. sublaevigatoides, Hale 1976, Swinscow \& Krog 1988). North America: Mexico (Hale 1976, Sipman \& Wolf 1998). Caribbean: Cuba, Haiti, Dominican Republic, Trinidad and Tobago (Hale 1976), South America: Chile (Galloway \& Quilhot 1998), Guyana (Feuerer 2008), Uruguay (Osório 1992), Venezuela (Hale 1976, López-Figueiras 1986, Marcano et al. 1996) and Brazil - Rio Grande do Sul (Canêz 2005) and São Paulo (Hale 1976, Osorio 1989, Marcelli 1990, 1991, 1993, Jungbluth 2006). This species is being cited for Porto Rico for the first time.

Additional selected specimens examined:New Caledonia, Mission Tejé, 1909, leg. G. Giamuier s.n. (DUKE). Papua New Guinea, MacDonald's Corner, near Port Moresby, on bark of rubber trees, leg. S.L. Thrower 2719, 30-VI-1976 (US). Indonesia, Java, corticola, in horto botanico Buitenzorgensi, ad Pandanum Bidur Jungh., leg. Overeem 335 (W!, holotype of Parmelia ochrovestita). Malaysia, Pahang State, oakdipterocarp forest, elev. About $1300 \mathrm{~m}$, vicinity of Frazier's Hill, leg. M.E. Hale 30134 4-III1965 (DUKE). South Africa, Pietersburg District, Bem Lavin Nature Reserve, near Louis Trichardt, 2329 BB, bushveld of mixed legume trees, leg. W.R. Buck 13405, 12-I-1986 (NY). Tanzania, Tanga Province, Usambara Mts., Amani, Road towards SW, on the trunk of a tree (Leguminosae) in a field, $5^{\circ} 8^{\prime} \mathrm{S}$,
38 37'E, 800-900 m, leg. R. Santesson 23422, 11-I-1971 (US). Uganda, Monte Eglon, alt. 1290 m, collector unknown XII-1914 (BM!, holótipo de Parmelia sublaevigatoides). Madagascar, Andrangolaoka, Imerina, leg. Hildebrandt s.n., XI-1880 (FH!, holotype of Parmelia meizosporoides Dodge). Mexico, Chiapas, $2 \mathrm{~km}$ north of highway 190 on road to Puebla Nueva west of Chiapas, Chiapa de Corzo, pine pasture, on conifers, ca. $1070 \mathrm{~m}$, leg. M.E. Hale \& T.R. Soderstrom 21067, 23III-1960 (US). Idem, Veracruz, $46 \mathrm{~km}$ southwest of junction of highway 140 and 155, northeast of Huatusco, hillside, scattered trees in coffee plantation, ca. $1020 \mathrm{~m}$, leg. M.E. Hale \& T.R. Soderstrom 19475, 13-III-1960 (US). Porto Rico, Distr. Arecibo, trail at end of Hwy 625, just outside of Observatório de Arecibo, ca. $18^{\circ} 22^{\prime} \mathrm{N}, 66^{\circ} 45^{\prime} \mathrm{W}, 265-295 \mathrm{~m}$, humid forest in limestone mogotes, leg. R.C. Harris 27598, 12-I-1992 (NY). Venezuela, Táchira, Via Rubio, Bramón, 800-1100 m, leg. M.E. Hale \& M. López Figueiras 45724 p. max. p., 24-III-1975 (US). Brazil, São Paulo, São Paulo Municipality, Parque Estadual da Cantareira, on tree branches in the woods, leg. M.N. Benatti 1410, VI-2000 (SP); idem, MogiGuaçu Municipality, Reserva Biológica de Mogi-Guaçu, Fazenda Campininha, on tree thin twig, leg. M.P. Marcelli \& M. Falco 33065, 2-IV-1999 (SP); idem, on tree trunk in the woods, leg. M.P. Marcelli \& M. Falco 34325, 14-IX-2000 (SP).

Comments - The holotype (Fig. 13) is dark brown, and the medullary acid is oxidized, the medulla completely stained with a rusty brown tint. It consists of two larger and one small fragments, all on bark, not glued to the cardboard. The fragments are quite brittle. There are a few pycnidia, but no conidia were found in them. The apothecia are poorly developed, and in almost all the hymenia are damaged. The duplicate consists of a fragment in the same poor conditions, also with the hymenial discs of the apothecia completely darkened and making it impossible to examine the ascospores. Although I cannot be sure if this fragment is really a duplicate, it was the only B. tabacina specimen located at PC; there is no collector's name, however the fragment do appear to have the same age and is in the 
Mycosphere Doi 10.5943/mycosphere/4/1/1

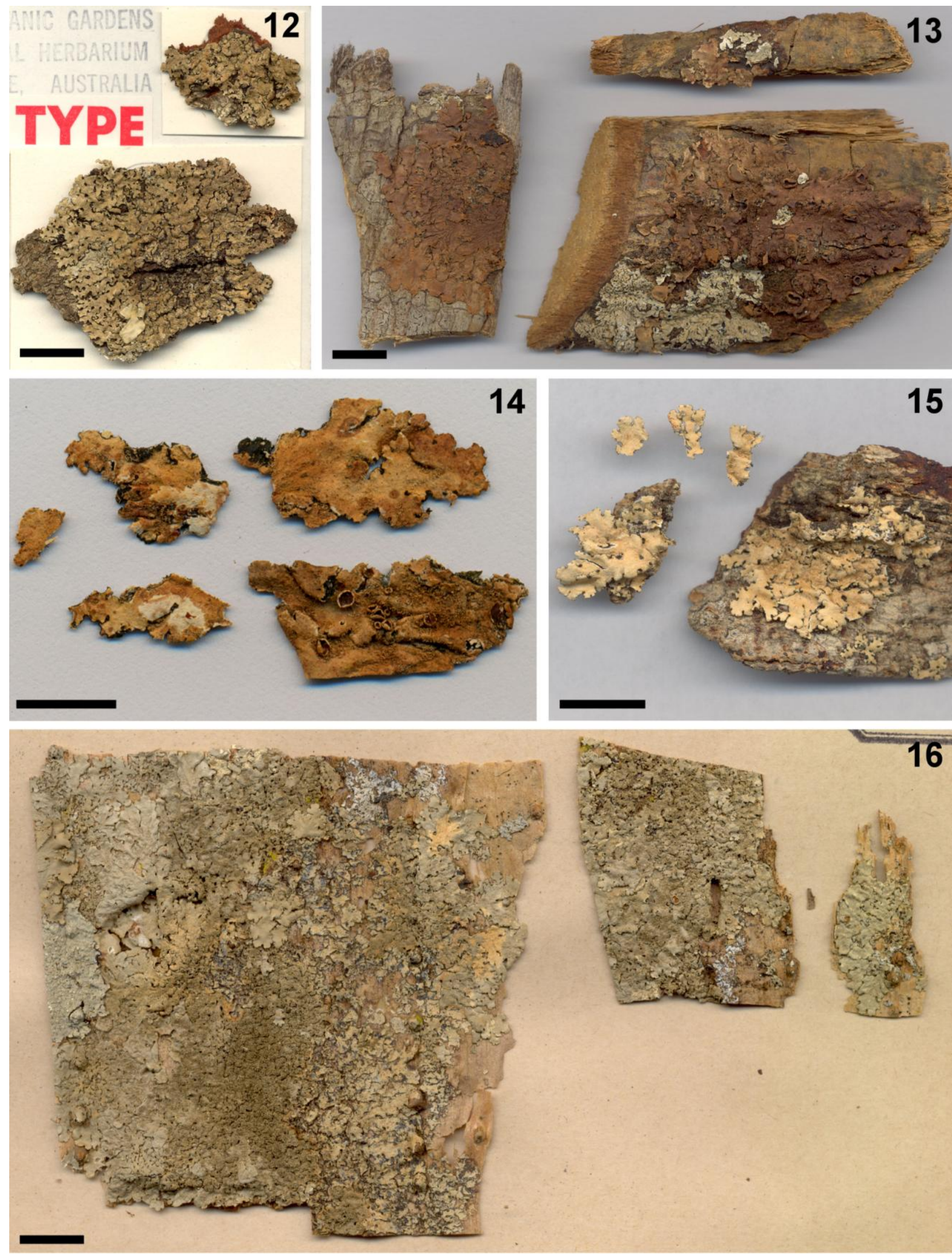

Figs 12-16 - 12 Holotype of Bulbothrix subtabacina (MEL). (US). 13 Lectotype of Bulbothrix tabacina (L). 14 Holotype of Parmelia meizosporoides (FH). 15 Holotype of Parmelia sublaevigatoides (BM). 16 Hlotype of Parmelia ochrovestita (W). Scale bars $=1 \mathrm{~cm}(12,13,14$, $15,16)$. 
same condition as the lectotype. By the description of Montagne \& Bosch (Montagne 1856), it is probable that the thallus was already on a very advanced stage of medullary substance deterioration at the type of its collection.

Bulbothrix tabacina is one of the most widely distributed species of the genus, cited for many tropical countries of almost all continents. According to Hale (1976), this is one of the species in the genus that can very easily be collected. Junghuhn (1855) cited a specimen from Java Island (Indonesia) one year before the publication of the species by Montagne \& Bosch (1856), mentioning the species and the page where it would be eventually found (in his descriptiom, Junghuhn describes the medulla as reddish brown, of a similar colour as tobacco, due to discoloration caused by oxidized salazinic acid). The species may well be found on twigs as well as on tree trunks.

The ascospore measurements cited by Hale (1976), Swinscow \& Krog (1988), Elix (1994) and Kurokawa \& Lai (2001) are all in accordance with those given here, varying between $9.0-15.0 \times 5.0-8.0 \mu \mathrm{m}$ to $12.0-15.0 \times$ 7.0-10.0 $\mu \mathrm{m}$, although no pseudosepta, as mentioned by Swinscow \& Krog (1988), were found in any specimen. Swinscow \& Krog (1988) described the species as emaculate having marginal cilia that are not always bulbate and occasionally bearing phylidia. None of these observations can be confirmed here.

Swinscow \& Krog (1988) and Elix (1994) mentioned saxicolous specimens of $B$. tabacina, but have accepted $B$. decurtata as a synonym. However, the saxicolous specimens of B. tabacina studied here display the same characteristics as the corticolous specimens, and these all differ from the characters observed in $B$. decurtata (see description and comments there). Unlike argued by Swinscow \& Krog (1988), and comparing the materials studied, $B$. decurtata is not accepted here as a synonym of $B$. tabacina. Instead the differences of the two species agree well with those already pointed out by Hale \& Kurokawa (1964). Bulbothrix decurtata (Hale \& Kurokawa) Hale (LD!, isotype at US!) thus differs from $B$. tabacina by being strictly saxicolous, with a frequently cracked emaculate upper cortex, having narrower (ca. 0.5-3.0 mm wide) and sublinear laciniae with usually truncate apices, smaller and blackened isidia, and by cilia with larger bulbs, which sometimes do elongate into cilia.

Regarding the accepted synonyms of $B$. tabacina, Parmelia meizosporoides (Fig. 14) was considered by Hale (1976) a synonym of Bulbothrix tabacina; this is confirmed here. The name Parmelia meizosporoides Dodge (1959) resulted from a validated description for the species (nomem nudum) called $P$. meizospora f. isidiosa Argoviensis by Müller (1884). In fact, in the work the name is only mentioned in a list, and only Zahlbruckner (1930) cited P. meizospora f. isidiosa in the synonymy of Parmelia amazonica Nyl.

Dodge (1959) described Parmelia meizosporoides with negative medullary reactions, however, the holotype (FH!) actually reacts to the $\mathrm{K}$ test, and contains medullary salazinic acid as seen in TLC/HPLC. The type material is saxicolous, and besides the ascospores were described as not exceeding 10 $\mu \mathrm{m}$ long, these were found to measure 9.0-13.0 (-15.0) × 4.0-6.5 (-7.5) $\mu \mathrm{m}$, with epispore 1.0-1.5 $\mu \mathrm{m}$. The holotype of Parmelia meizosporoides has clear medullae, in better condition than the holotype of Bulbothrix tabacina. Dodge already mentioned the bulbate cilia, indicating that the margins of the thallus were "papillate". The specimen was described with more sublinear laciniae ca. $1 \mathrm{~cm}$ wide, but has laciniae 1.5-4.0 mm wide.

The holotype (Fig. 15) of Parmelia ochrovestita (Zahlbruckner 1928) is probably the same species as Bulbothrix tabacina, but it displays a number of atypical features. Although it shares all of the morphological variation seen in other specimens of $B$. tabacina, the holotype of Parmelia ochrovestita is characterized by more sublinear, more narrow laciniae $(1.0-3.0 \mathrm{~mm}$ wide.), it is pale greyish, and its lower cortex has elongate, attenuated pale brown margins. The whole thallus gradually becomes darker towards it center where it eventually become completely blackened. The isidia are very abundant, covering large portions of the 
thallus, they are thus not quite like the relatively scarce isidia seen on most other specimens of B. tabacina.

Studies of the holotype specimen (Fig. 16) of Parmelia sublaevigatoides Dodge (1959) also suggest that this taxon should be considered a synonym of $B$. tabacina. Its laciniae are slightly narrower than usual (although in accordance with the minimum found), and they are also more sublinear often with subtruncate apices. However, the specimen is clearly small and undeveloped. The material bears no apothecia or pycnidia. Dodge mentioned $P$. sublaevigatoides in his key as not isidiate, however, the material has sparse isidia, smaller than commonly found in the specimens of $B$. tabacina. Due to the immature condition of the holotype it appears that laciniae and isidia did not yet reach their maximum width and size.

Dodge (1959) cited medullary chemical reactions as negative for this species. However, the thallus clearly contains medullary salazinic acid, with its typical $\mathrm{K}+$ reaction, confirmed also by TLC/HPLC (this has been annotated on the label already by T.D.V. Swinscow mentioning the mistake by Dodge, although no indication is given by which method the presence of salazinic acid was confirmed). The upper cortex of the specimen does not react $\mathrm{K}^{-}$ as mentioned by Dodge, but it is clearly $\mathrm{K}+$ yellow due to the presence of atranorin.

Bulbothrix isidiza (H-Nyl! holotype) was compared to B. decurtata by Hale (1976) and is probably the most similar species in both morphology and medullary chemistry. However, thalli of $B$. isidiza tend to be mor densely isidiate than those of B. tabacina, and the lower cortex is pale brown from the margins to the center, with little variation in tone. Marcelli (1993) and Canêz (2005) cited B. tabacina specimens with a brown lower cortex with darker parts, but these are in fact specimens of $B$. isidiza.

Bulbothrix ventricosa (TUR-V! lectotype) can be differentiated by the constant formation of laminal ciliar bulbs, denser isidia, a lower cortex of variable colour (often mixed brown and black tones), and by the presence of medullary norstictic acid. Althought Jungbluth (2006) mentioned that $B$. ventricosa had wider laciniae than B. tabacina $(1.5-4.5 \times 1.0-2.5$ $\mathrm{mm}$ wide), the material studied (Benatti 2012a) showed that the variation is similar in both species. She also described specimens with an emaculate surface, but they actually have weak and sparse maculae.

Hale (1976) compared Bulbothrix laevigatula (Nyl.) Hale (H-Nyl 35653!, duplicate at PC!) to B. tabacina, and this species differs by the narrow, sublinear dichotomously branched laciniae (ca. 0.5-2.0 mm wide), dichotomously branched cilia and rhizines, and by the presence of medullary lecanoric acid.

Jungbluth (2006a) and Jungbluth et al. (2008) compare B. cassa Jungbluth, Marcelli \& Elix (SP!, holotype) to B. tabacina. Bulbothrix cassa is morphologically similar, differing by the brown lower córtex and by the presence of a medullary fatty acid instead of salazinic acid.

Bulbothrix subtabacina (holotype at MEL!, isotype at CANB!) differs by the more linear, dichotomous, and narrow laciniae $(0.5-1.0 \mathrm{~mm}$ wide) with truncate apices, very cracked upper cortex, commonly ciliate isidia and by the dichotomously branched cilia and rhizines.

\section{Nomina Inquirenda}

Parmelia demangei Harmand, Annales Cryptogamae Exotiques 1: 327. 1928. MB 397447

Holotype - Indochina, leg. Demange 37 (P, accordingly to Hale 1976a, n.v.).

Comments - The type material was not located at P or PC. This species is accepted as a synonym of $B$. isidiza by Hale (1976). As described by Harmand (1928) Parmelia demangei has a \pm orbicular whitish thallus ca. 5 $\mathrm{cm}$ in diameter, membranaceous, smooth and somewhat shiny, with scattered or grouped laminal isidia $0.2-0.4 \mathrm{~mm}$ high, sinuous and incised-lobed laciniae $1.0-3.0 \mathrm{~mm}$ wide, that are very irregularly lacinulate, has crenate margins, rounded to sometimes subtruncate apices, rounded axils, dark olive green lower cortex with dense dark brown simple to branched rhizines 0.5 to $1.0 \times 0.06 \mathrm{~mm}$, both upper and lower cortices ca. $9 \mu \mathrm{m}$ thick, the medulla and algal layer ca. $60 \mathrm{~m}$ thick. He 
described two reactions: $\mathrm{K}+$ yellow (possibly the upper cortex, due to atranorin) and $\mathrm{K}+$ yellow $\rightarrow$ blood red (typical for medullary salazinic acid).

Harmand (1928) described the "rhizines usually triming the edge of the thallus having the appearance of cilia." His comment that it was "a sterile lichen which appears to have been collected with the bark, without a precise location." As a lacinulate lichen with an olive lower cortex (a colour commonly seen in Pseudoparmelia thalli) it may be a synonym, but could also be a morphologically distinct species similar to $B$. isidiza. However, from the description alone, this is impossible to tell and thus it will be necessary to first locate the type material.

Parmelia recurviscens Harmand, Annales Cryptogamae Exotiques 1: 326. 1928.

MB 398151

Holotype - Indochina, leg. Demange 36 (P, accordingly to Hale 1976a, n.v.).

Comments - The type material was not located at $\mathrm{P}$ or PC. This species is also accepted as a synonym of $B$. isidiza (Nylander) Hale by Hale (1976). As described by Harmand (1928) Parmelia recurviscens has a membranaceous to subcoriaceous greyish thallus, with a slightly pinkish tone in the center, a somewhat shiny smooth surface, scarce isidia disposed in small clusters, 0.3 to 4.0 (could be a typo, 0.4 ?) $\mathrm{mm}$ high, laciniae 2.0-5.0 mm wide, subrotund or elongated, irregularly lacinulate to crenate and lobulate, incised, slightly imbricate, with rounded or subtruncate apices and angular axils, a densely rhizinate, castaneous brown lower cortex, black rhizines $0.3-1.0 \mathrm{~mm}$ long, both upper and lower cortices ca. $9 \mu \mathrm{m}$ thick, algae layer ca. $45 \mu \mathrm{m}$ thick, medullae ca. $66 \mu \mathrm{m}$ thick, apothecia $0.30-0.35 \mathrm{~mm}$ in diam., concave, disc castaneous brown, smooth, margin denticulate, containing 8 ascospores per ascus, simple, hyaline, oval, $12.0 \times 6.0-6.5 \mu \mathrm{m}$. Again, he described two reactions: $\mathrm{K}+$ yellow (possibly the upper cortex, due to atranorin) and $\mathrm{K}+$ yellow $\rightarrow$ blood red (typical for medullary salazinic acid).

The only comment made by Harmand (1928) was "uncertain locality". As with $P$. demangei, it is possible to make just a few comments about this species. The taxon is possibly a synonym of $B$. isidiza and not one of $P$. demangei. The author described the laciniae as "all visibly coated (perhaps by rhizines? He does not mention eyelashes...) followed up the edges." Although it is unclear as which character he actually means, it is quite possible that he meant bulbous marginal cilia.

As with $P$. demangei, it is possible to make just a few comments about this species, but $P$. recurviscens seems more likely to be a synonym of $B$. isidiza than of $P$. demangei. Harmand (1928) described the laciniae and the lacinulae "all visibly covered (by rhizines perhaps? he did not mention cilia) following up the edges." Although it is unclear to which character this statment refers, it is quite possible that he meant the bulbate marginal cilia.

\section{Acknowledgements}

The author wishes to thank the curators of BM (Scott LaGrecca), CANB (Brendan Lepschi), DUKE (Kathleen Pryer), H (Leena Myllys), HUFSCAr, L (Gerard Thijsse), LD (Arne Thell), MEL (Josephine Milne), MSC (L. Alan Prather), NY (Barbara Thiers), PC (Bruno Dennetière), TNS (Yoshihito Ohmura), and US (Rusty Russell) for loans or access to type specimens and additional material, John A. Elix for HPLC data on the species secondary metabolites, Frank Bungartz for the English review, comments, and suggestions, and the reviewers for critical revision of the manuscript.

\section{References}

Aptroot A 1990 - Lichens of Madagascar: new and interesting records and species. Cryptogamie, Bryologie et Lichenologie 11(4) 401-408.

Asahina Y. 1957 - Lichenologische Notizen (124-125). Journal of Japanese Botany 32(4) 97-100.

Awasthi DD. 1976 - Lichen genus Parmelia in India I - Subgenera Parmelia and Amphigymnia. Biological Memoirs 1(1-2) 155-229.

Benatti MN, Marcelli MP. 2010 - Four 
Parmeliaceae species excluded from Bulbothrix. Mycotaxon 111, 387-401.

Benatti MN. 2010 - Revisão do gênero Bulbothrix Hale. PhD Thesis. Instituto de Botânica, São Paulo.

Benatti MN. 2011 - A simple clearing technique to aid in the recognition of cilia and rhizinae struture in the Parmeliaceae. Opuscula Philolichenum 9, 21-25.

Benatti MN. 2012a - A review of the genus Bulbothrix Hale: the species with medullary norstictic and protocetraric acids. MycoKeys 2, 1-28.

Benatti MN. 2012b - Three resurrected species of the genus Bulbothrix Hale (Parmeliaceae, Lichenized Fungi). Mycosphere 3, 46-55.

Benatti MN. 2012c - A review of the genus Bulbothrix Hale: the species with medullary salazinic acid without vegetative propagules. MycoKeys (in prep.)

Bibliotheca Lichenologica 86, 1-7.

Bock C, Hauck M, Fischer E. 2007 - The lichen flora of Rwanda: an annotated checklist. Willdenowia 37, 563-575.

Brako L, Dibben MJ, Amaral I. 1985 Preliminary notes on the macrolichens of Serra do cachimbo, Northcentral Brazil. Acta Amazonica, suplement 15(1-2): 123-135.

Brodo IM, Sharnoff SD, Sharnoff S. 2001 Lichens of North America. Yale University Press, New Haven \& London. $795 \mathrm{p}$.

Bungartz F. 2001 - Analysis of lichen substances. ASU lichen herbarium. http://nhc.asu.edu/lichens/lichen_info/tlc. jsp\#TLC2 [accessed 20 July 2008].

Calvelo S, Adler MT 1999 - Parmelia araucana sp. nov. and new reports in the Parmeliaceae sensu stricto (lichenized Ascomycotina) from Patagonia and Tierra del Fuego (Argentina). Sydowia 51(2), 145-154.

Canêz LS 2005. A Família Parmeliaceae na localidade de Fazenda da Estrela, Município de Vacaria, Rio Grande do Sul, Brasil. Master's Dissertation. Instituto de Botânica, São Paulo.

Crespo A, Kauff F, Divakar PK, del Prado R,
Pérez-Ortega S, de Paz G A, Ferencova $Z$, Blanco O, Roca-Valiente B, NúñezZapata J, Cubas P, Argüello A, Elix JA, Esslinger TL, Hawksworth DL, Millanes AM, Molina MC, Wedin M, Ahti T, Aptroot A, Barreno E, Bungartz F, Calvelo S, Candan M, Cole MJ, Ertz D, Goffinet B, Lindblom L, Lücking R, Lutzoni F, Mattsson JE, Messuti MI, Miadlikowska J, Piercey-Normore MD, Rico VJ, Sipman H, Schmitt I, Spribille T, Thell A, Thor G, Upreti DK, Lumbsch HT. 2010 - Phylogenetic generic classification of parmelioid lichens (Parmeliaceae, Ascomycota) based on molecular, morphological and chemical evidence. Taxon 59, 1735-1753.

Des Abbayes H 1961 - Lichens recoltes a Madagascar et a la Reunion (Mission $\mathrm{H}$. Des Abbayes, 1956). I. - Introduction. II. - Parmeliacees. Memoirs del Institute Scientifique de Madagascar, ser. B 19(2), 81-121.

Dey JP 1987 - The distribution of the lichen, Bulbothrix isidiza, in North America north of Mexico. The Bryologist 90(4), 417-418.

Din LB, Zakaria Z, Elix JA 2004 - Additional lichen records from Indonesia and Malaysia 5. Lichens from Bukit Larut, Peninsula Malaysia. Australasian lichenology 55, 10-12.

Divakar PK, Crespo A, Blanco O, Lumbsch HT 2006 - Phylogenetic significance of morphological characters in the tropical Hypotrachyna clade of parmelioid lichens (Parmeliaceae, Ascomycota). Molecular Phylogenetics and Evolution 40(2), 448458.

Divakar PK, Upreti DK 2005 - Parmelioid Lichens in India - a Revisionary Study. Bishen Singh Mahendra Pal Singh, India. $488 \mathrm{p}$.

Dodge CW 1959 - Some lichens of tropical Africa III. Parmeliaceae. Annals of the Missouri Botanical Garden 46, 39-193.

Eliasaro S 2001 - Estudio taxonomico y floristico sobre las parmeliaceae sensu stricto (Ascomycota liquenizados) del Segundo Planalto del Estado de Paraná, Brasil. Tese de Doutorado. Universidad 
de Buenos Aires.

Elix JA $1993^{\mathrm{a}}$ - Progress in the generic delimitation of Parmelia sensu lato lichens (Ascomycotina: Parmeliaceae) and a synoptic key to the Parmeliaceae. The Bryologist 96, 359-383.

Elix JA 1993b - New species in the lichen family Parmeliaceae (Ascomycotina) from Australia. Mycotaxon 47, 101-129.

Elix JA 1994 - Bulbothrix. In Orchard, A.E., Grgurinovic, C. (eds.) Flora of Australia, Lichens. Introduction, Lecanorales 2. vol. 55. Australia Government Publishing Service, Canberra, p. 13-19.

Elix JA 2001 - Additional lichen records from Oceania 7. Parmeliaceae from Fiji. Australasian Lichenology 48, 34-37.

Elix JA, Giralt M, Wardlaw JH 2003 - New chloro-depsides from the lichen Dimelaena radiata. Bibliotheca Lichenologica 8,: 1-7.

Elix JA, Stevens GN 1979 - New species of Parmelia (lichens) from Australia. Australian Journal of Botany 27, 873883.

Feuerer T, Marth C. 1997 - Anatomy of pseudocyphellae and bulbate cilia in Parmeliaceae. Mitteilungen aus dem Institut für Allgemeine Botanik in Hamburg 27, 101-107.

Feuerer TE (ed.) 2008 -Checklists of lichens and lichenicolous fungi. Version 1 September 2008. In http://www.checklists.de

Fleig M, Grüninger W 2000a - Liquens do Pomar Cisne Branco e arredores, Sao Francisco de Paula, Rio Grande do Sul, Brasil. Iheringia, Série Botânica [Porto Alegre] 53, 67-78.

Fleig M, Grüninger W 2000b - Levantamento preliminar dos liquens do Centro de Pesquisas e Conservação da Natureza Pró-Mata, São Francisco de Paula, Rio Grande do Sul, Brasil. Napaea 12, 5-20.

Fleig M, Riquelme I 1991 - Liquens de Piraputanga, Mato Grosso do Sul, Brasil. Acta Botanica Brasilica 5, 3-12.

Galloway DJ, Quilhot W 1998 - Checklist of Chilean lichen-forming and lichenicolous fungi. Gayana Botanica 55(2), 111-185.
Hale ME 1971 - Five new Parmeliae from tropical America. Phytologia 22, 30-35.

Hale ME 1974 - Bulbothrix, Parmelina, Relicina, and Xanthoparmelia, four new genera in the Parmeliaceae. Phytologia 28, 479-490.

Hale ME. 1975. A monograph of the lichen genus Relicina (Parmeliaceae). Smithsonian Contributions to Botany 26, 1-32.

Hale ME 1976 - A monograph of the lichen genus Bulbothrix Hale (Parmeliaceae). Smithsonian Contributions to Botany 32, 1-29.

Hale ME 1986 - New species in the lichen family Parmeliaceae (Ascomycotina). Mycotaxon 25, 85-93.

Hale ME, Kurokawa S. 1964 - Studies on Parmelia subgenus Parmelia. Contributions from the. United States national Herbarium 36(4), 121-191.

Harmand J 1928 - Lichens d'Indo-Chine recueillies par M.V. Demange. Annales de Cryptogamie Exotique 1, 319-337.

Harris RC 1987 - Four lichens new to North America collected on the 1985 ABLS Foray in Florida. Evansia 4, 26-27.

Hue AM 1899 - Lichenes extra-europaei a pluribus collectoribus ad Museum Parisiensi missi. Nouvelles Archives du Muséum d'Histoire Naturelle de Paris 1, 27-220.

Jungbluth P 2006 - A família Parmeliaceae (fungos liquenizados) em fragmentos de cerrados do Estado de São Paulo. Master's Dissertation. Instituto de Botânica, São Paulo.

Jungbluth P, Marcelli, MP, Elix JA. 2008 Five new species of Bulbothrix (Parmeliaceae) from cerrado vegetation in São Paulo State, Brazil. Mycotaxon 104, 51-63.

Junghuhn F 1855 - Plantae Junghuhnianae. Enumeratio plantarum, quas in Insulis Java et Sumatra detexit. Fasc. IV, Lugduni Batavorum, 1851-1855, 427494.

Killmann D, Fischer E. 2005 - New records for the lichen flora of Rwanda, East Africa. Willdenowia 35, 193-204. 
Krog H 2000 - Corticolous macrolichens of low montane rainforests and moist woodlands of eastern Tanzania. Sommerfeltia 28, 1-75.

Kumar M, Sequiera S. 2001 - On a collection of macrolichens from New Amarambalam Reserve Forests, southern Western Ghats, India. Journal of Economic and Taxonomic Botany 25(1): 239-246.

Kurokawa S 1993 - Nepalese genera and species of the Parmeliaceae with notes on three additional and one rare species. Annals of the Tsukuba Botanical Garden $12,75-81$.

Kurokawa S, Lai MJ 2001 - Parmelioid lichen genera and species in Taiwan. Mycotaxon 77, 225-284.

Lopez-Figueiras M. 1986 - Censo de macroliquenes venezolanos de los estados Falcon, Lara, Merida, Tachira y Trujillo. Facultad de Farmacia, Universidad de Los Andes, Merida. 521 p.

Louwhoff SHJJ, Elix JA 2000 - The lichens of Rarotonga, Cook Islands, South Pacific Ocean II: Parmeliaceae. Lichenologist 32(1), 49-55.

Louwhoff SHJJ, Elix JA 2002 - The Parmeliaceae (lichenized Ascomycota) of New Caledonia. Lichenologist 34(5), 373-394.

Marcano V, Morales-Méndez A, Sipman H, Calderon L. 1996 - A first checklist of the lichen-forming fungi of the Venezuelan Andes. Tropical Bryology 12, 193-235.

Marcelli MP 1990 - Liquens de restingas e manguezais da ilha do Cardoso. Anais do II Simpósio de Ecossistemas da Costa Sul e Sudeste Brasileira (Águas de Lindóia, SP). Vol 3, 382-392.

Marcelli MP 1991 - Aspects of the foliose lichen flora of the southern-central coast of São Paulo State, Brazil. In: Galloway DJ (ed). Tropical Lichens: Their Systematics, Conservation, and Ecology, Systematics Association Special Vol. 43, p. 151-170. Clarendon Press, Oxford.

Marcelli MP 1993 - Pequenas Parmelia s.l. Ciliadas dos Cerrados Brasileiros. Acta Botanica Brasilica 7(2), 25-70.
Montagne JFC. 1856 - Sylloge generum specierumque cryptogamarum, quas in variis operibus descriptas iconibusque illustratas, nunc ad diagnosum reductas, nonnullasque novas interjectas, ordine systematica exposuit. Paris. XXIV, 1-498 p.

Müller Argoviensis J. 1884 - Lichenologische Beiträge, XX. Flora 67, 613-621.

Müller Argoviensis J. 1894 - Lichenes Usambarenses. In: Engler A., Beiträge zur Flora von Afrika, IX. Englers Botanische Jahrbücher 20: 238-272.

Nash TH, Elix JA. 2002 - Bulbothrix. In: Nash, TH, Ryan BD, Gries C, Bungartz F (eds.) Lichen Flora of the Greater Sonoran Desert Region. I. Lichens Unlimited, Arizona State University, Tempe, Arizona, pp. 114-116.

Nylander W 1884 - Lichenes. In: Henriques J., Contribuição para o estudo da Flora d'algumas possessões portuguezas. I. Plantas colhidas por F. Newton na Africa occidental. Boletim da Sociedade Broteriana Coimbra 3, 130-131.

Osorio HS 1989 - Contribution to the lichen flora of Brazil. XXIII. Lichens from São Paulo City. Mycotaxon 36(1), 161-162.

Osorio HS 1992 - Contribucion a la flora liquénica del Uruguay. XXV. Líquens publicados entre 1972 a 1991. Anales del Museo Nacional de Historia Natural de Montevideo (Series 2) 8, 43-70.

Pereira WR, Marcelli MP. 1989 (1991) Liquens da Reserva Biológica do Alto da Serra de Paranapiacaba. Acta Botanica Brasilica 3(2) Suplement: 89-94.

Ribeiro CH 1998 - A família Parmeliaceae (Ascomycota liquenizados) em Regiões montanhosas dos estados de Minas Gerais, Rio de Janeiro e São Paulo. Master's Dissertation, Instituto de Biociências da Universidade de São Paulo. 194p.

Sérusiaux E. 1984 - Contribution to the study of lichens from Kivu (Zaire), Rwanda and Burundi. VIII. New and interesting species of parmeliaceous lichens. The Bryologist 87, 1-11.

Sipman HJM, Aubel RJMT. 1992 - New Parmeliaceae (Lichenes) from the 
Guianas and surroundings. Mycotaxon 44(1), 1-12.

Sipman HJM, Wolf JHD 1998. - Provisional checklist for the lichens of Chiapas. Acta Botanica Mexicana 45, 1-29.

Streimann H 1986 - Catalogue of the Lichens of Papua New Guinea and Irian Jaya. Bibliotheca Lichenologica 22. J. Cramer, Berlin and Stuttgart. 145p.

Swinscow TDV, Krog H. 1978 - The genus Dirinaria in East Africa. Norwegian Journal of Botany 25, 157-168.

Swinscow TDV, Krog H. 1988 - Macrolichens of East Africa. British Museum of Natural History. London. 390p.

Vainio (Wainio) EA 1901 - Lichenes. In: Catalogue of African plants collected by
F. Welwitsch in 1853-61, vol. 2, pt. 2, pp. 396-463.

Wolseley PA, Aguirre-Hudson B. 1997 - The ecology and distribution of lichens in tropical deciduous and evergreen forests of northern Thailand. Journal of Biogeography 24, 327-343.

Wu J-n, Xiang T, Qian Z-g 1986 - Notes on Wuyi Mountain lichens (IV). Wuyi Science Journal 6, 285-292.

Zahlbruckner A 1928 - Neue und ungenügend beschriebene javanische Flechten. Annales de Cryptogamie Exotique 1: 109-212.

Zahlbruckner A 1930 - Catalogus Lichenum Universalis. Vol 6. Borntraeger, Leipzig. $618 \mathrm{p}$. 